\title{
Using the balance sheet approach in surveillance: framework, data sources, and data availability ${ }^{1}$
}

\author{
Johan Mathisen and Anthony Pellechio ${ }^{2}$
}

\section{Introduction}

A distinguishing feature of emerging market crises in the 1990s and early 2000s was the sudden disruption in the capital accounts of key sectors of the economy. Capital account crises typically occur as creditors quickly lose confidence, prompting sudden and large-scale portfolio adjustments, such as massive withdrawals of bank deposits, panic sales of securities, or abrupt halts of debt rollovers. As the exchange rate, interest rates, and other asset prices adjust, the balance sheet of an entire economy can sharply deteriorate.

These crises highlighted the need for closer attention to vulnerabilities in sectoral balance sheets. As a result, the International Monetary Fund (IMF) intensified development of the balance sheet approach (BSA) to examining macroeconomic vulnerabilities.

Since the start of this more intense effort in $2002,{ }^{3}$ the BSA has been increasingly applied as part of the IMF's bilateral surveillance activities (Box 1$).{ }^{4}$ This paper draws on this experience and on progress made in meeting the data demands for the BSA in order to draw lessons for the most effective framework for this type of analysis. The main objectives are to provide guidance on how best to design the analytical framework - in terms of delineation of sectors and financial instruments - in order to address particular country circumstances, and to give an update on recent improvements in statistical methodologies and data availability that are enhancing the BSA's potential as a surveillance tool by allowing for a more detailed and timely analysis.

The BSA examines the balance sheets of key sectors of an economy in a framework that facilitates the identification and analysis of vulnerabilities. It tries to explain the dynamics of a capital account crisis by examining stocks of assets and liabilities. As such, the BSA departs from the traditional financial programming approach whose flow-based analysis examines the build-up of unsustainable fiscal and current account positions over time. By focusing instead on shocks to stocks of assets and liabilities, which can trigger large adjustments in capital flows, the BSA can be a useful complement to the traditional flow analysis. As such, it encourages analysts to look more broadly in monitoring and assessing economic and financial conditions.

1 This paper was previously published as IMF Working Paper WP/06/100.

2 The authors are indebted to many colleagues, as predecessors, collaborators, and reviewers including, in the Policy Development and Review Department, Mark Allen, Juha Kahkonen, Tessa van der Willigen, Dominique Desruelle, Christoph Rosenberg, Brett House, and Johannes Wiegand; in the Statistics Department, Rob Edwards, William Alexander, Edgar Ayales, Neil Patterson, Roberto Rosales, Robert Heath, Jaroslav Kucera, José Carlos Moreno, Simon Quinn, and Justin Matz; and, in other departments, Andreas Billmeier, Marcos Chamon, Mark De Broeck, Robert P. Flood, Dale Gray, Cheng Hoon Lim, Paolo Manasse, Paolo Mauro, and Mariana Torres. Authors' E-Mail Addresses: jmathisen@imf.org and apellechio@imf.org.

3 While the paper by Allen and others (2002) marked the launch of a systematic application of the BSA, development of crisis models based on analysis of sectoral balance sheets date at least to the Mexican crisis of 1994-95. This included work at the IMF such as Bussière and Mulder (1999) and Johnston, Chai, and Schumacher (2000).

4 See Rosenberg and others (2005) and the IMF's biennial surveillance review (IMF, 2004a). 
The basic sequence of accounts of the IMF's System of National Accounts 1993 (known as the 1993 SNA) provides the internationally accepted, comprehensive, and integrated framework for both flows and stocks for an economy and, thus, the BSA (Figure 1). The current accounts at the beginning of this sequence record the production of goods and services, income generation and distribution, and use of income for consumption and saving. This is followed by the accumulation accounts that record the acquisition and disposal of financial and non-financial assets and liabilities, and changes in net worth. Finally, the balance sheets show the value of the stock of assets and liabilities of institutions and sectors at the beginning and end of the accounting period. The balance sheet completes the sequence of accounts, showing the final result of the entries in the production, distribution, and use of income, and accumulation accounts. These balance sheets are the building blocks of the BSA.

Figure 1

Interrelationships of the balance sheets and accumulation accounts

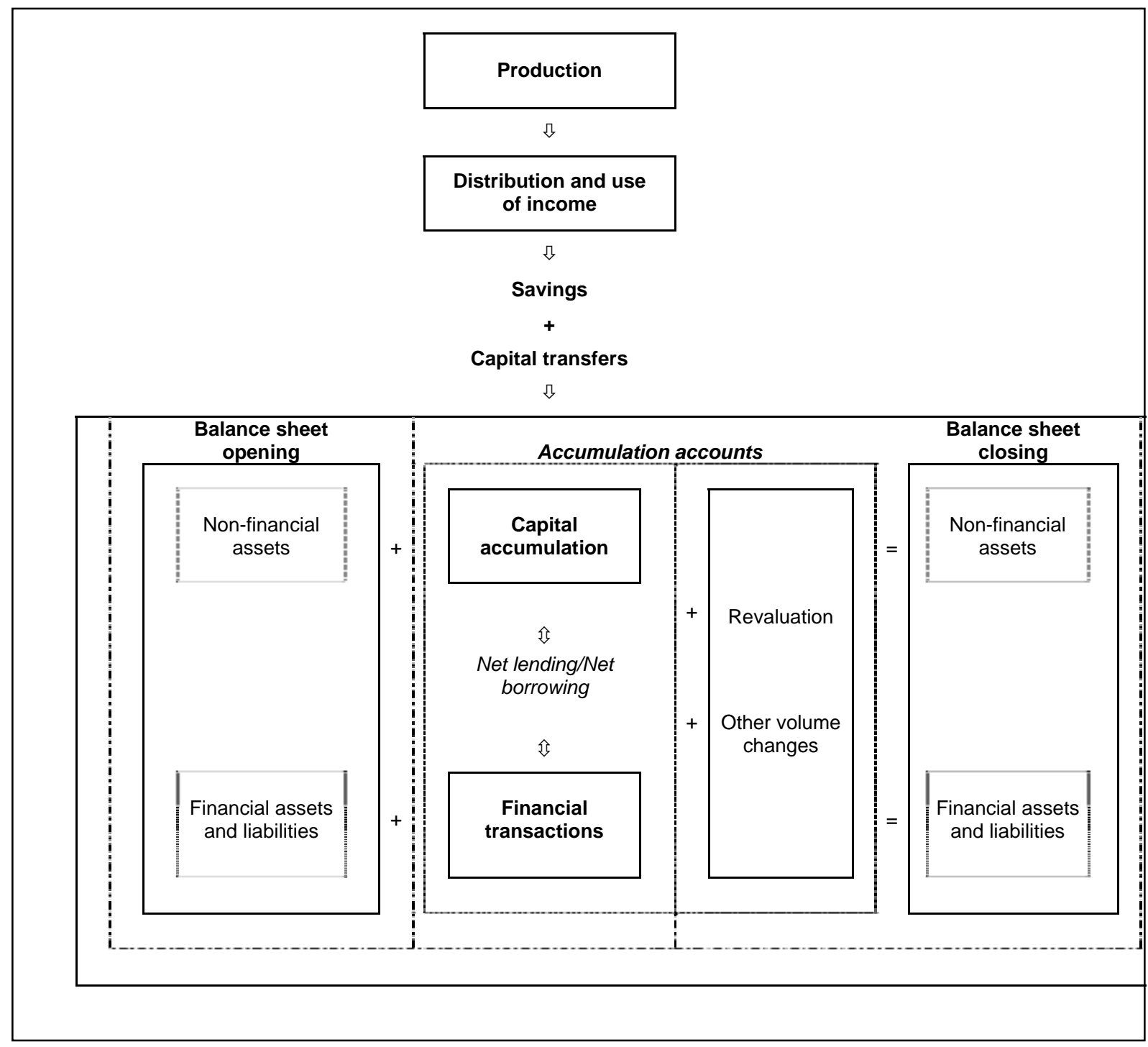




\section{Box 1}

\section{Recent country examples of balance sheet analysis}

Chile: http://www.imf.org/external/pubs/ft/scr/2003/cr03312.pdf

Ecuador: http://www.imf.org/external/pubs/ft/scr/2003/cr0391.pdf

Thailand: http://www.imf.org/external/pubs/ft/scr/2004/cr0401.pdf

Peru: $\quad$ http://www.imf.org/external/pubs/ft/scr/2004/cr04156.pdf

Bulgaria: http://www.imf.org/external/pubs/ft/scr/2004/cr04177.pdf

Ukraine: http://www.imf.org/external/pubs/ft/scr/2005/cr0520.pdf

Colombia: http://www.imf.org/external/pubs/ft/scr/2005/cr05162.pdf

Belize: http://www.imf.org/external/pubs/ft/scr/2005/cr05353.pdf

Russia: http://www.imf.org/external/pubs/ft/scr/2005/cr05379.pdf

Turkey: Turkey at a Crossroads - From Crisis Resolution to EU Accession, IMF Occasional Paper 242, 2005.

In addition, some of the key results of the balance sheet analysis of Brazil are published at http://www.imf.org/external/np/pdr/bal/2004/eng/070104.htm.

The data requirements of the BSA depend on its specification of sectors and financial instruments, as well as on the vulnerabilities being analyzed. The analyst should try to specify a framework based on the important risks or mismatches to be analyzed and on the available data for a country. The BSA can be applied without having a full set of data for all sectors and could be pursued to the extent that data are available and timely for useful empirical and policy analysis. To the extent possible, data used in the BSA should be produced following internationally accepted methodologies based on the 1993 SNA to minimize inconsistencies.

The availability of data for applying the BSA, whose gaps in the past hindered the assessment of vulnerabilities for macroeconomic policymaking, has improved. ${ }^{5}$ Efforts to incorporate the balance sheet approach into the IMF's work have been supported by recent statistical and transparency initiatives. Requirements for the special data dissemination standard (SDDS) have improved the dissemination of data and metadata on public and external debt, international reserves and foreign currency liquidity, international investment positions, and analytical accounts of the banking sector. This, in turn, has led to improvements in methodologies and data availability, including the following:

- $\quad$ Recently introduced standardized report forms (SRFs) for monetary and financial sector data, which represent a significant step in providing the breakdown by currency and maturity for assets and liabilities required by the BSA. The SRF data are submitted monthly with a high level of detail standardized across countries.

- $\quad$ The online quarterly external debt statistics (QEDS) introduced in 2004 and the international investment position (IIP) data, which constitute a significant advance in the availability of data for the BSA. The QEDS is based on the External Debt Statistics Guide for Compilers and Users, developed by an inter-agency task force chaired by the IMF to measure and monitor external debt. The guide meets BSA data requirements, notably currency and maturity breakdowns (IMF, 2003).

5 The latest review of data provision to the IMF for surveillance purposes indicated that balance sheet analysis had been generally hampered by lack of availability of currency and maturity breakdowns, particularly on public debt and assets and liabilities of the non-financial private sector. 
- $\quad$ The joint external debt hub (JEDH), which is an online database based on creditor and market sources for the external debt of 175 countries. The JEDH was launched jointly in March 2006 by the Bank for International Settlements (BIS), the IMF, the Organization for Economic Cooperation and Development (OECD), and the World Bank.

- $\quad$ The coordinated portfolio investment survey (CPIS), which has improved the availability and comparability of statistics on countries' portfolio investment positions.

\section{Main objectives of the balance sheet approach}

The purpose of the BSA is to analyze vulnerabilities of sectors and transmission mechanisms among them. Key vulnerabilities that the BSA framework aims to capture can be summarized as follows: ${ }^{6}$

- $\quad$ Maturity mismatches between short-term liabilities and longer-term assets expose borrowers to rollover risk (ie, the inability to refinance maturing debts) and interest rate risk (the differential impact of interest rate movements on asset and liabilities, depending upon interest rate structure). For instance, maturity mismatches in foreign currency may create difficulties if, due to a change in market conditions, domestic borrowers do not have enough liquid foreign currency assets to cover short-term foreign currency debt. Financial entities that borrow in the short term to invest in long-term debt instruments with fixed interest rates would suffer from a rise in interest rates (eg, due to cyclical developments or an interest rate defense of an exchange rate peg), which may have a significant impact on their liquidity or solvency.

- $\quad$ Currency mismatches arise when borrowers' liabilities are denominated in a foreign currency but their assets are in domestic currency. In the event of a sharp depreciation, these borrowers may well have trouble paying their creditors. Experience in a number of countries has shown that, in certain circumstances (eg, longstanding fixed exchange rate regimes), borrowers and lenders may well underestimate exchange rate risk.

- $\quad$ Capital structure mismatches may occur when a firm or a country relies on debt rather than equity to finance investment. Equity provides a buffer during hard times, because dividends drop along with earnings, whereas debt payments remain unchanged. At the country level, financing current account deficits with debt (particularly short-term debt) rather than direct investment has typically been seen as generating greater vulnerability.

In times of crisis, these risks are typically manifested as liquidity or solvency problems. Liquidity problems are generally associated with inadequate resources to cover short-term payment requirements. Solvency problems might arise when an entity's liabilities are not commensurate with its assets and the net present value of future net income streams - for example, when government debt is too high in comparison with government assets and the net present value of primary surpluses. Liquidity and solvency problems might be separate events, but can be related, as when, for example, solvency problems spill over into liquidity problems or repeated liquidity problems raise concerns about solvency.

$6 \quad$ As described in Rosenberg and others (2005). Other market risks that stem from potential sharp declines in the price of assets, such as government bonds, real estate, or equities, should be considered key balance sheet risks if exposure is sufficiently large. 
Maturity, currency, and capital structure mismatches can all increase the risk that a negative shock will cause liquidity problems or drive large parts of one or more sectors into insolvency (Calvo and Reinhart, 2002, Reinhart and others, 2003a).

Often these problems are not evident, as maturity or currency mismatches are hidden in indexed or floating-rate debt instruments, making them less apparent. In some emerging market economies, liabilities may be formally denominated in local currency, but indexed to the exchange rate. Similarly, the nominal maturity of an asset may be long, but the interest rate it bears may be floating.

The BSA is designed to identify key indicators of a sector's vulnerability, including the following:

- Net financial position, defined as financial assets minus financial liabilities: ${ }^{7}$ a large negative position can point to solvency problems, especially if leverage - debt as a share of total liabilities - is high;

- $\quad$ Net foreign currency position, defined as foreign currency assets minus foreign currency liabilities: a sector with a large negative (positive) position is vulnerable to exchange rate depreciation (appreciation); and

- $\quad$ Net short-term position, defined as short-term assets minus short-term liabilities: a large negative short-term position indicates vulnerability to interest rate increases and to rollover risk.

\section{Key features of the framework for analysis}

The particular framework of a BSA application - a matrix of intersectoral balance sheets (Table 1) in terms of sectors of the economy and components of the balance sheet depends on the focus of analysis and, as a practical matter, availability of data. Allen and others (2002) provide a generic matrix encompassing four sectors (government, financial, non-financial, non-resident) with assets and liabilities broken down by (short- and long-term) maturity and currency (domestic, foreign). The framework presented in this paper uses the same breakdown of assets and liabilities but expands it to seven sectors. ${ }^{8}$

This framework follows standard practice in balance sheet analysis: a sector's liabilities to other sectors (debtor positions) are presented along the horizontal axis and its claims (creditor positions) on other sectors on the vertical axis. Each row of the framework presents the sector's liability structure by currency, maturity, and creditor, and each column presents the corresponding asset structure, that is, its holdings of other sectors' liabilities.

\footnotetext{
Balance sheet analysis is largely based on financial statistics. Real assets, such as real estate - often a major component of public assets - are therefore not included, as they are not sufficiently liquid to be usable in a crisis. The concept of net financial position is therefore different from the net worth (or implied capital) often used to assess whether the operations of the entity (or sector) can be sustained over the medium to long term. A balance sheet analysis is not intended to reflect the "true economic position" of an economy or sector, but merely its macroeconomic vulnerability.

8 The 1993 SNA defines five broad sectors: (1) general government; (2) financial corporations (including the central bank); (3) non-financial corporations (including public non-financial corporations); (4) households and non-profit institutions serving households; and (5) rest of the world. This paper follows the sectorization of the Monetary and Financial Statistics Manual (IMF, 2000) and defines three subsectors within the 1993 SNA's financial corporations sector - the central bank, other depositary corporations, and other financial corporations - as separate sectors, bringing the number of sectors to seven.
} 
Table 1

Intersectoral asset and liability position matrix

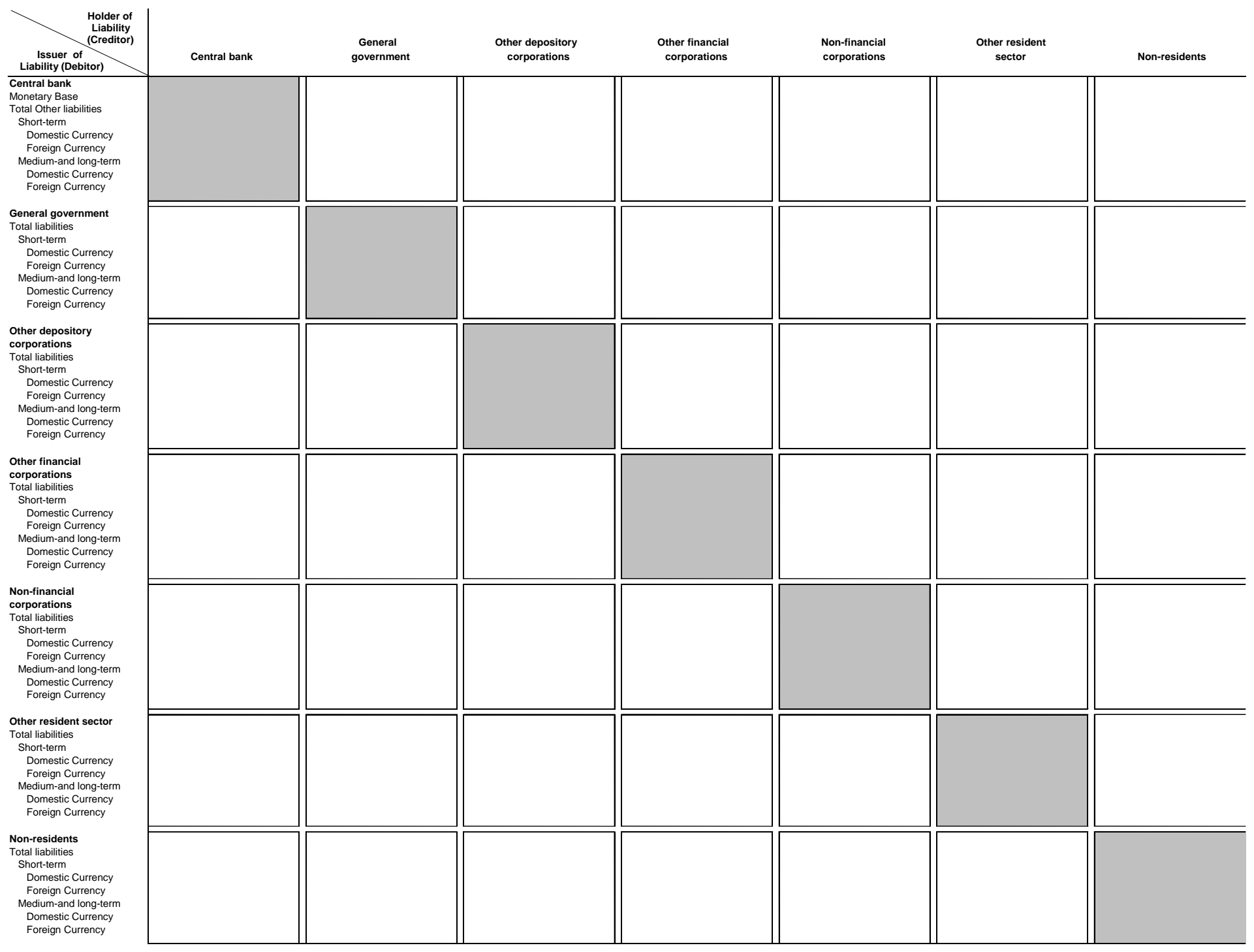


Table 2

South Africa: intersectoral asset and liability matrix (December 2004)

In million of rand

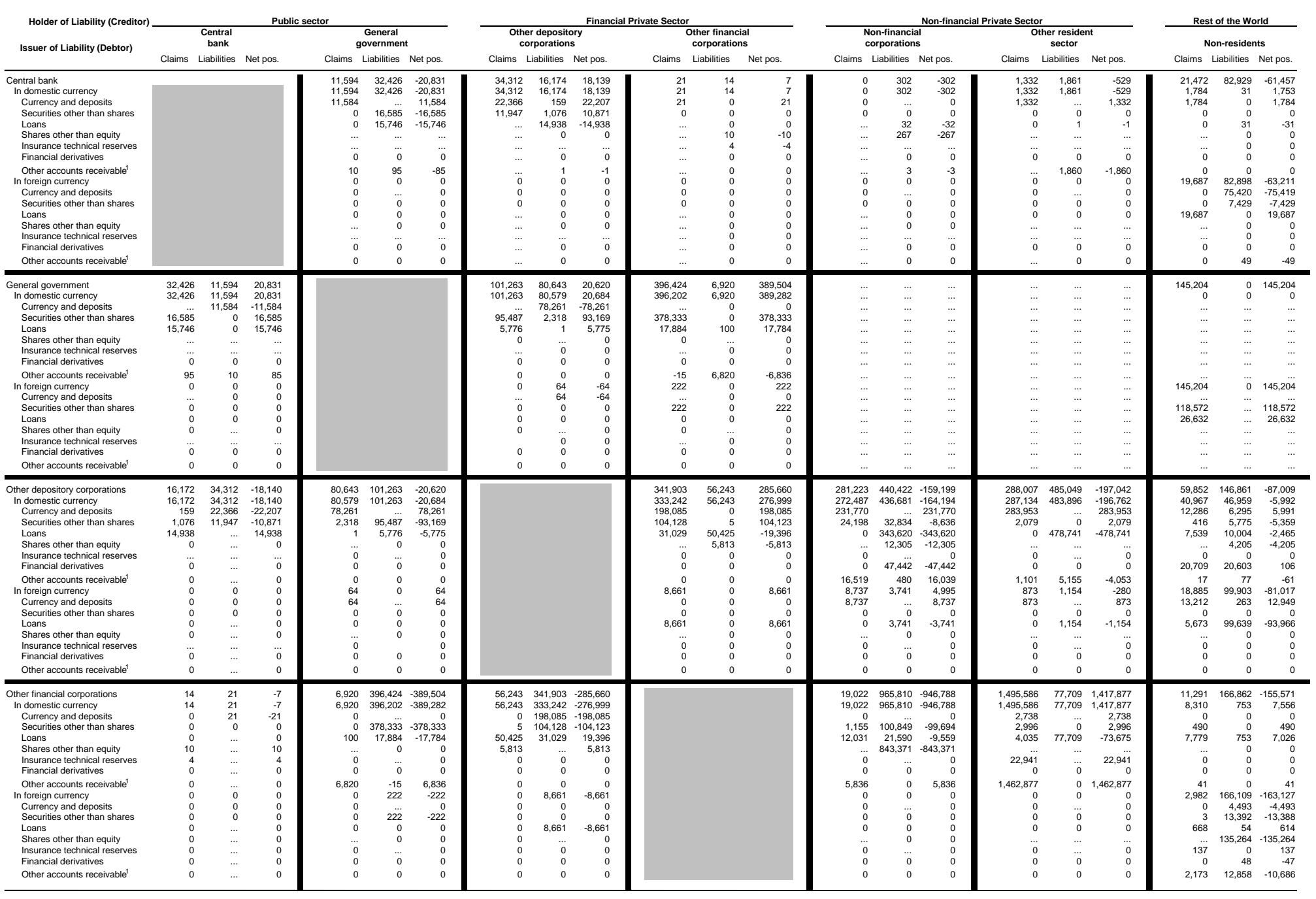


Table 2 (cont)

South Africa: intersectoral asset and liability matrix (December 2004)

In million of rand

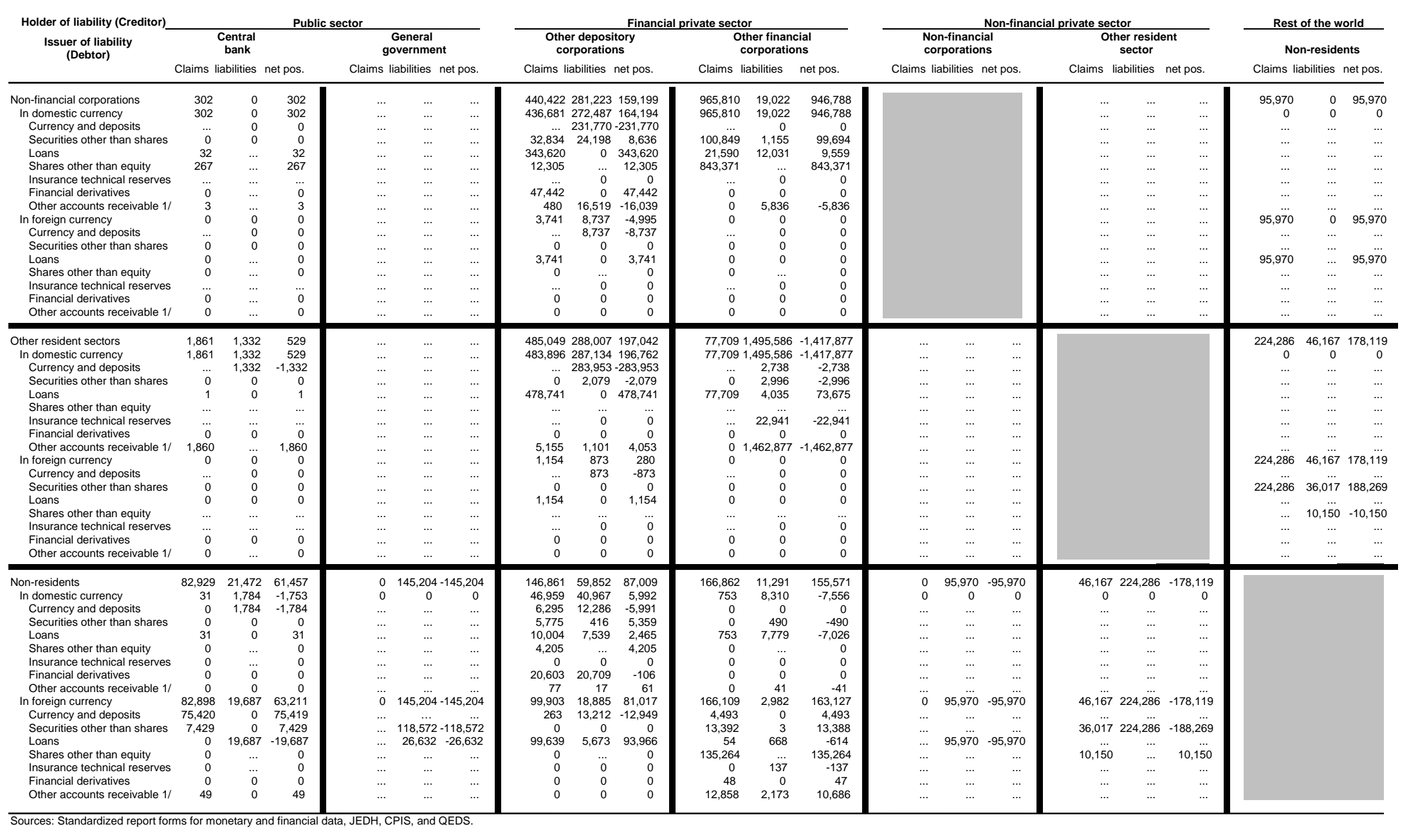

$1 /$ Includes trade credittadvances, settlement accounts, new equity of households in life insurance and pension funds (if applicable). 
By way of illustration, the BSA framework was completed for South Africa using data from the recently introduced SRFs for monetary and financial statistics, QEDS, and CPIS (Table 2). The high level of detail of these data provides a fairly comprehensive picture of net positions of one sector against another, along with the underlying claims and liabilities. Another advantage is the inclusion of currency denomination of all assets and liabilities.

The guiding principle in establishing the framework for balance sheet analysis is that it must appropriately support the macroeconomic analysis. The appropriate framework for policy analysis should be determined by the country-specific risks or mismatches to be analyzed. Thus, the framework is flexible, as it can be and has been adapted to meet the analytical requirements and data availability for particular cases. The level of complexity of the matrix can vary by delineation of economic sectors, financial instruments, maturity, and currency denomination, which is discussed below.

The BSA framework presented in this paper is closely related to the traditional flow-of-funds matrix, which aggregates sectoral assets, liabilities, and net positions, but differs by estimating intersectoral assets and liabilities, that is, each sector's position vis-à-vis that of other domestic sectors as well as non-residents. Many countries, especially developed and larger emerging market economies, have developed comprehensive financial statistics that easily lend themselves to flow-of-funds analysis. In those instances where the underlying data used to compile the financial statistics are sufficiently detailed to estimate intersectoral positions by currency and maturity, this data source would be the logical choice to compile the BSA matrix. A key benefit of this framework is to provide important information that is netted out in the consolidated country balance sheet. Sectoral balance sheets can reveal significant vulnerabilities and their potential transmission among sectors that remain hidden in the consolidated country balance sheet. A matrix of intersectoral positions can reveal how a high level of dollarization is a source of vulnerability by contributing to the creation of a country-wide balance of payments crisis. The intersectoral matrix of asset and liabilities - a key innovation of the balance sheet approach - can shed light on how difficulties in one sector spill over into other healthy sectors through financial linkages.

\section{A. Sectorization}

The main guidance for sectorization is to group institutional units into sectors of the economy based on the similarity of their objectives, principal functions, behavior, and the types of units that control them. The most important aspect of this methodology is control, which can be defined as the power to govern the financial and operating policies of another entity so as to benefit from its activities. Appropriate sectorization is essential to ascertain, for example, which assets the authorities can draw on in times of crisis.

Distinguishing between the public and private sector is by far the most important delineation for analysis of macroeconomic vulnerabilities (Figure 2). Identifying which financial assets are under control of the authorities - or would be in times of crisis - is essential because a policy response to a macroeconomic calamity such as the collapse of the banking system would most likely take the form of a transfer of resources between the public and private spheres. To estimate the public sector's financial positions vis-à-vis other sectors, it is important not only to identify public units, but also to properly distinguish between public and private corporations. ${ }^{9}$ Although this might be very difficult to ascertain, a benchmark might be

9 The 1993 SNA distinguishes between public corporations and general government on the basis of economic activity. Public corporations are entities that are controlled by the government but are engaged in market activities. From the point of view of risk assessment, however, this may not be the only criterion to consider. For example, some corporations operating in the market may not be controlled by government, but still have their liabilities covered by explicit or implicit government guarantees, thus resulting in public sector contingent 
whether government control over the corporation is currently exercisable. For example, do the authorities have the power, conferred by legislation, to appoint directors and influence dividend payments? General regulatory powers applicable to a class of entities or industry are not sufficient to distinguish between public and private enterprises.

The 1993 SNA's sectorization, which is based on economic activity rather than control, can be simplified to accommodate the BSA's data requirements. A fundamental requirement in many cases is the availability of data on the banking sector, as banks' balance sheets are central to the allocation and transmission of risk in any economy. The 1993 SNA's sectorization (Table 3) could be modified to be very close or identical to the sectorization described in IMF (2000), the Monetary and Financial Statistical Manual (MFSM) (Appendix I). The main advantage of this sectorization is its compatibility with the new SRFs for monetary and financial statistics, as published in International Financial Statistics (IMF, 2001a). ${ }^{10}$ The sectorization of the SRFs will be maintained in the foreseeable future. In most countries these statistics are available owing to accounting and regulatory standards applied to the financial sector. This is important, as this sector's position can affect the health of many other sectors in the economy.

liabilities, as discussed in Board papers on public investment and fiscal policy and government guarantees and fiscal risk.

10 The sectorization presented in this paper is also compatible with External Debt Statistics: Guide for Compilers and Users (IMF, 2003, paragraphs 3.4 to 3.12). 
Figure 2

Sectorizing public entities

General government versus public corporations ${ }^{1}$

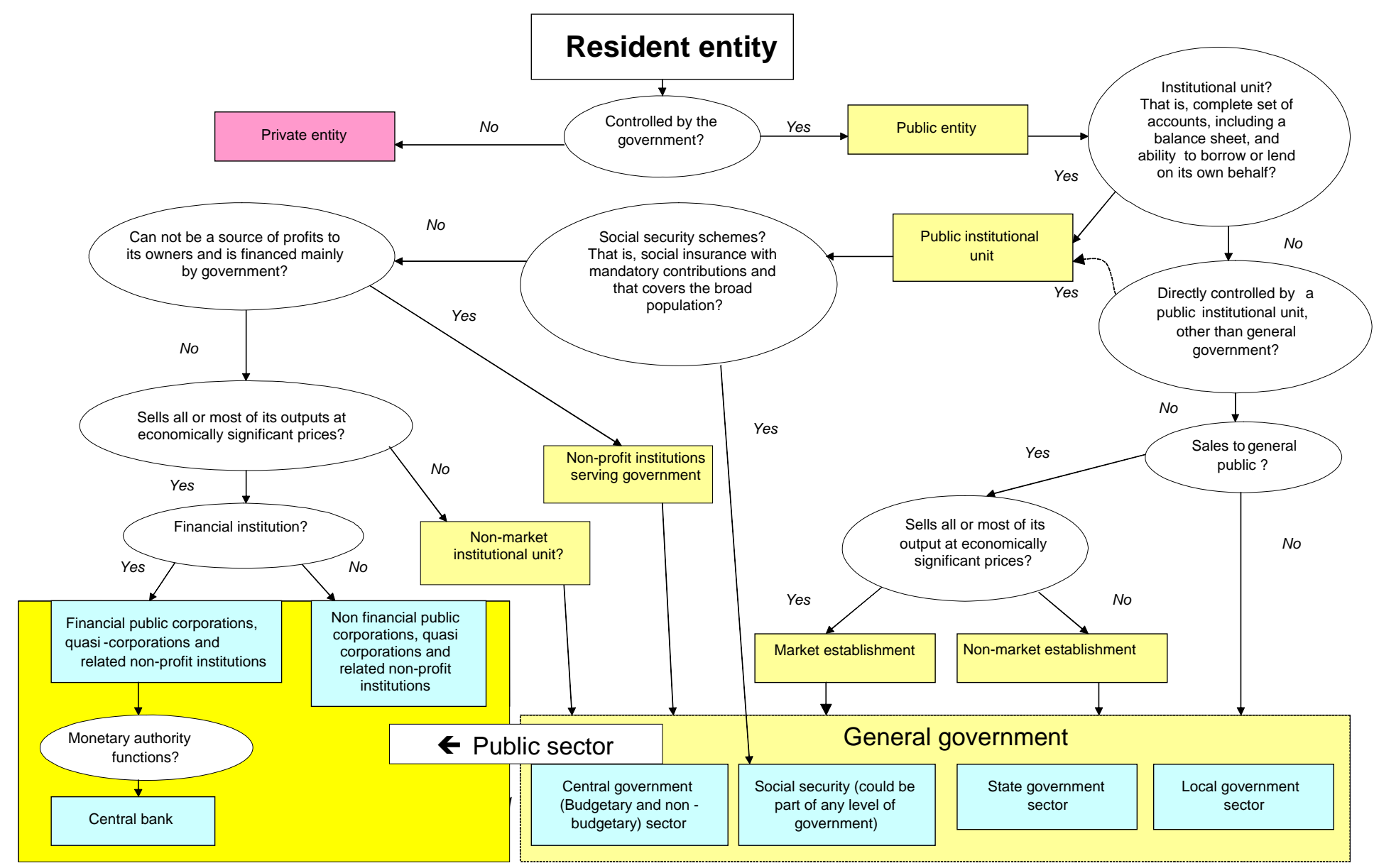

1 The GFS system covers all resident public entities, that is all entities that have a center of economic interest in the economic territory of the domestic economy (see paragraphs 2.70-2.77 in the GFSM 2001). 
Table 3

Sectors and financial instrument categories

\begin{tabular}{|c|c|}
\hline Sectors $^{1}$ & Financial instrument categories ${ }^{2}$ \\
\hline $\begin{array}{l}\text { Total economy } \\
\text { Non-financial corporations } \\
\text { Public non-financial corporations } \\
\text { National private non-financial corporations } \\
\text { Foreign controlled non-financial } \\
\text { corporations } \\
\text { Financial corporations } \\
\text { Central bank } \\
\text { Other depository corporations } \\
\text { Deposit money corporations } \\
\text { Public } \\
\text { National private } \\
\text { Foreign controlled } \\
\text { Other depository corporations, except } \\
\text { deposit money corporations } \\
\text { Public } \\
\text { National private } \\
\text { Foreign controlled } \\
\text { Other financial intermediaries, except } \\
\text { insurance corporations and pension funds } \\
\text { Public } \\
\text { National private } \\
\text { Foreign controlled } \\
\text { Financial auxiliaries } \\
\text { Public } \\
\text { National private } \\
\text { Foreign controlled } \\
\text { Insurance corporations and pension funds } \\
\text { Public } \\
\text { National private } \\
\text { Foreign controlled }\end{array}$ & $\begin{array}{l}\text { Gold and SDR } \\
\text { Gold } \\
\text { SDR holdings } \\
\text { Currency and deposits } \\
\text { Bank notes and coins } \\
\text { Bank deposits } \\
\text { Non-bank financial inst. deposits } \\
\text { Central government deposits } \\
\text { Local government deposits } \\
\text { Social security funds deposits } \\
\text { Public non-financial corp. deposits } \\
\text { Other non-financial corp. deposits } \\
\text { Other resident deposit } \\
\text { Foreign notes and coins } \\
\text { Deposits with/from non-residents } \\
\text { Securities other than shares } \\
\text { Treasury bills } \\
\text { Treasury bonds } \\
\text { Local government securities } \\
\text { Financial corp. securities' } \\
\text { Public non-financial corporations securities } \\
\text { Other non-financial corporations securities } \\
\text { Securities issued by non-residents } \\
\text { Shares and other equity } \\
\text { Financial corp. shares } \\
\text { Non-financial corp. shares } \\
\text { Foreign shares } \\
\text { SDR allocation } \\
\text { Loans } \\
\text { Central bank (CB) loans }\end{array}$ \\
\hline
\end{tabular}


Table 3 (cont)

\section{Sectors and financial instrument categories}

\begin{tabular}{|c|c|}
\hline Sectors $^{1}$ & Financial instrument categories ${ }^{2}$ \\
\hline General government & Loans to banks other than CB loans \\
\hline General government classification & Loans to non-bank financial inst. \\
\hline alternatives $^{\perp}$ & Loans to central government \\
\hline Central government & Loans to state and local government \\
\hline State government & Loans to public non-financial corp. \\
\hline Local government & Loans to other non-financial corn \\
\hline Social security funds & Mortgage loans \\
\hline Central government social security & Other loans \\
\hline State government social security & Loans to other residents \\
\hline funds & Mortgage loans \\
\hline Local government social security & Other loans \\
\hline & Loans to/from non-residents \\
\hline $\begin{array}{l}\text { General government classification } \\
\text { alternatives }^{2}\end{array}$ & Insurance technical reserves \\
\hline Central government & Insurance reserves for residents \\
\hline Central government & Insurance reserves for non-residents \\
\hline Central government social security & Pension reserves \\
\hline funds & Financial derivatives \\
\hline State government & Other accounts receivable/payables \\
\hline State government & Other accounts with residents \\
\hline State government social security & Other accounts with non-residents \\
\hline funds & Gold and SDR \\
\hline Deposit money corporations & Gold \\
\hline Local government & SDR holdings \\
\hline $\begin{array}{l}\text { Local government social security } \\
\text { funds }\end{array}$ & Currency and deposits \\
\hline Households & Bank notes and coins \\
\hline Employers & Bank deposits \\
\hline Own account workers & Non-bank financial inst. deposits \\
\hline Employees & Central government deposits \\
\hline Recipients of property and transfer income & Local government deposits \\
\hline Deposit money corporations & \\
\hline Deposit money corporations & \\
\hline Deposit money corporations & \\
\hline Non-profit institutions serving households & \\
\hline Rest of the world & \\
\hline
\end{tabular}


Sectorization can be customized, as in the application of the BSA to Colombia (Lima and others, 2006), where the balance sheets of individual institutions were aggregated into sectoral balance sheets, with sectors specifically defined to identify vulnerabilities and their transmission among sectors. All information was carefully checked by sector experts at the Colombian central bank for consistency, a time-consuming and exceptional undertaking. The economy was split into nine sectors: the non-financial public sector, the central bank, private banks, public banks, private non-bank intermediaries, public non-bank intermediaries, large and medium-sized companies, households and small companies, and the external sector. Based on this sectorization, the application of the BSA to Colombia analyzes the evolution of macroeconomic and financial vulnerabilities between 1996 and 2003, a period that encompasses a severe recession in 1999 and a currency and banking twin-crisis, both following the Russian crisis of 1998.

Even when balance sheet data for all main sectors are not available, the BSA can be applied to examine the vulnerabilities of a particular sector known to be problematic. The examination of important individual sectoral balance sheets can help to detect weaknesses that have the potential to spill over into other sectors, as follows:

- $\quad$ Financial sector. Balance sheets of the central bank and financial sector are key to assessing the main risks and overall resilience to shocks. Commercial banks' balance sheets are central to the allocation and transmission of risk in any economy. Analysis of the balance sheets of systemically important financial institutions is the core work in preparing Financial Sector Assessment Programs and other financial sector surveillance. Maturity transformation - taking in short-term deposits to extend longer-term loans - is fundamental to financial intermediation, giving rise to the wellknown risk of deposit runs. The financial systems of emerging market countries often face challenges not typically found in advanced economies. To accommodate loan demand, banks may tap foreign credit lines; to attract depositors, banks may offer foreign currency deposits; as a consequence of high public sector deficits, banks may have a large exposure to government debt, enhancing the potential for spillovers between the financial and public sectors; and weak supervision may not identify increasing balance sheet risks in a timely manner or at all.

- $\quad$ Public sector. High levels of sovereign debt and weaknesses in its structure can make the balance sheets of government a potential source of vulnerability to the economy.

- Non-financial corporate sector. Balance sheets of the non-financial corporate sector can be a source of vulnerability if a significant part of corporate debt is owed by corporations with inadequate capital and liquidity or earning power (as in the case of Indonesian toll roads that owed debt in foreign currency).

Vulnerabilities of the non-financial corporate sector have been analyzed recently using microlevel data on corporations to fill the gap left by more readily available aggregate data for the public and financial sectors. A new database that combines balance sheet and debt issuance data at the firm level for 15 emerging market countries has been used to analyze vulnerabilities in corporate finance. ${ }^{11}$ The analysis shows that emerging market corporations have substantial maturity and currency mismatches on their balance sheets that may become a source of financial instability if the external environment of low interest rates and appreciating emerging market currencies becomes less favorable. This suggests that firms' exposures to market risk factors, such as exchange rates and interest rates, should be considered jointly, with the associated vulnerability measures reflecting the interaction among these factors.

11 The database was developed for the Global Financial Stability Report (IMF, 2005, Chapter IV). 


\section{B. Classification and valuation of financial instruments}

The analysis should preserve the commonly used breakdown of financial instruments, if available in the source data (Appendix II). The key advantage of maintaining a high level of detail is that it facilitates estimating intersectoral assets and liabilities by financial instrument, which may be particularly useful if the economy is widely dollarized. However, this benefit should be weighed against the cost of handling a large dataset.

The main delineation of financial instruments for macroeconomic vulnerability analysis is between equity and nonequity instruments. ${ }^{12}$ Countries that finance substantial current account deficits with debt from unrelated parties incur more risk than those receiving foreign direct investment and equity portfolio investment flows (Roubini and Setser, 2004). Firms relying on debt rather than equity financing may be more vulnerable during crisis, as debt repayments are required regardless of circumstances.

Country circumstances may call for a more detailed analysis of certain categories of financial instruments. For example, liquidity analysis requires estimates of liquid foreign currency assets and short-term foreign currency liabilities of the banking system. In particular, in economies where dollarization in the financial sector is pronounced and maturity mismatches between foreign currency assets and liabilities are pervasive, runs on foreign currency deposits in domestic banks can trigger external difficulties (IMF, 2004b, pp. 11-12).

Solvency risk analysis and debt sustainability analysis focus on characteristics of central government debt. Many emerging market governments had difficulty placing long-term debt in their own currency on the domestic market. The critical mass needed to develop a sufficiently deep market may be lacking, or investors may simply lack confidence in the stability of the domestic currency - an important factor in many Latin American and Middle Eastern countries where legacies of high inflation are still fresh. In this situation, governments resorted to issuing debt formally denominated in local currency, but indexed or linked to the exchange rate, as in the cases of Mexico and Brazil. ${ }^{13}$ This creates currency risk similar to debt denominated in foreign currency, because a depreciation of the domestic currency increases the burden of foreign currency-linked debt in domestic currency terms for resident debt holders.

The nominal maturity of an asset may be long, but the interest rate it bears may be floating, effectively shortening duration. Such floating rate debt creates the same interest rate risk as if the maturity were as short as the frequency of interest rate adjustments. In this case, data should be compiled according to the frequency of interest rate adjustment.

The method of valuing financial assets and liabilities might depend on the focus of the analysis. In general, the standard market valuation principle applies, but nominal values might be useful in certain circumstances, in particular for debt instruments. For example, applying nominal values might help identify maximum exposure, which can be used to assess liquidity risk. Also, if the timing of recording between creditors and debtors in financial account transactions is not consistent, it may aggravate the level of discrepancies in the dataset to the extent it affects end-period stocks.

12 As indicated in footnote 5 the framework presented in this paper concerns financial assets and liabilities, and does not address the net worth of a sector or economy.

13 Mexico has not issued exchange-rate-linked debt since its 1994 crisis. For Brazil, instruments indexed to the exchange rate have represented a small share of total domestic debt of government, as it has placed instruments indexed to inflation and interest rates in the domestic market as well. This share increased temporarily under extreme market pressures, but returned to low levels as exchange-rate-indexed instruments were replaced by other instruments when circumstances returned to normal. 
Ideally, all financial claims should be examined in a macroeconomic vulnerability analysis based on their estimated market values subject to stress testing. The valuation of some instruments - deposits, for example - will not be affected when the economy is under stress. For other instruments, such as currency holdings and liabilities, a crisis could entail an offsetting or easily quantifiable impact on both sides of the balance sheet.

For a certain group of claims characterized by a high degree of uncertainty over their value ${ }^{14}$ - such as insurance, financial derivatives, and contingent claims ${ }^{15}$ - the impact of a crisis on their value could be asymmetric and significant. These claims might call for a different treatment than allowed by traditional financial statistics, which require that claims have demonstrable value. Several approaches have been developed to assess the risk posed by these claims in sectoral balance sheets. For example, stress testing examines scenarios corresponding to different degrees of risk exposure owing to these claims to help determine a likely range of exposure under each scenario. ${ }^{16} \mathrm{~A}$ stochastic simulation can be employed to compute a probability distribution of possible debt outcomes around baseline estimates.

Government guarantees are potentially important contingent claims that need to be considered. There are two main types of government contingent future obligations: those that become due if certain events materialize, such as defaults on government guaranteed debt; and those that result from the government's implicit or "moral" commitment, for example, to protect depositors or pay pensions. The BSA can help assess the potential for problems with these contingent future obligations of the government by identifying vulnerabilities and potential pressures.

\section{Levels of complexity}

The complexity of the framework in terms of sectorization and delineation of financial instruments for macroeconomic balance sheet vulnerability analysis should be adapted to the particular country circumstances. As discussed above, the specification of sectors and financial instruments can vary according to the risks or mismatches to be analyzed and available data. However, the potential for a very detailed analysis, for example, based on the 1993 SNA for the sectoral breakdown and MFSM for delineation of the financial instruments, is substantial (Table 3). The desired level of detailed analysis has to be weighed against the cost of obtaining and handling more detailed data.

Some of this complexity can be overcome by focusing on the key relationships between particular sectors and financial instruments, in particular for currency mismatch analysis (Figure 3). (Reinhart and others, 2003b,)

For example, in many countries the main foreign currency liabilities of the general government are its external debt, as the central bank is acting as its agent for other foreign currency transactions. Similarly, the foreign-currency-denominated assets of other financial corporations are traditionally confined to deposits in the banking system and holdings of securities (usually claims against non-residents) and, on the liability side, these corporations

14 See IMF (2003, Chapter 9) for a detailed discussion.

15 The literature usually distinguishes between three types of contingent obligations: legally binding guarantees to take on an obligation should a clearly specified uncertain event materialize (eg, trade or exchange rate guarantees); a broader set of obligations that gives rise to an explicit contingent liability (eg, government insurance schemes, including deposit, pension, war-risk, crop, and flood insurance); and an implicit contingent liability when there is an expectation to take on an obligation despite the absence of a contractual or policy commitment to do so (eg, bailing out public enterprises).

16 See Appendix IV of the IMF's "International Reserves and Foreign Currency Liquidity: Guideliens for a Data Template." Available via the Internet: http://dsbb.imf.org/Applications/web/sddsguide/. 
might have issued securities or contracted loans in foreign currency (Goldstein, Morris, and Turner, 2004)

Figure 3

Common foreign currency balance sheet relationships in partially dollarized emerging market economies

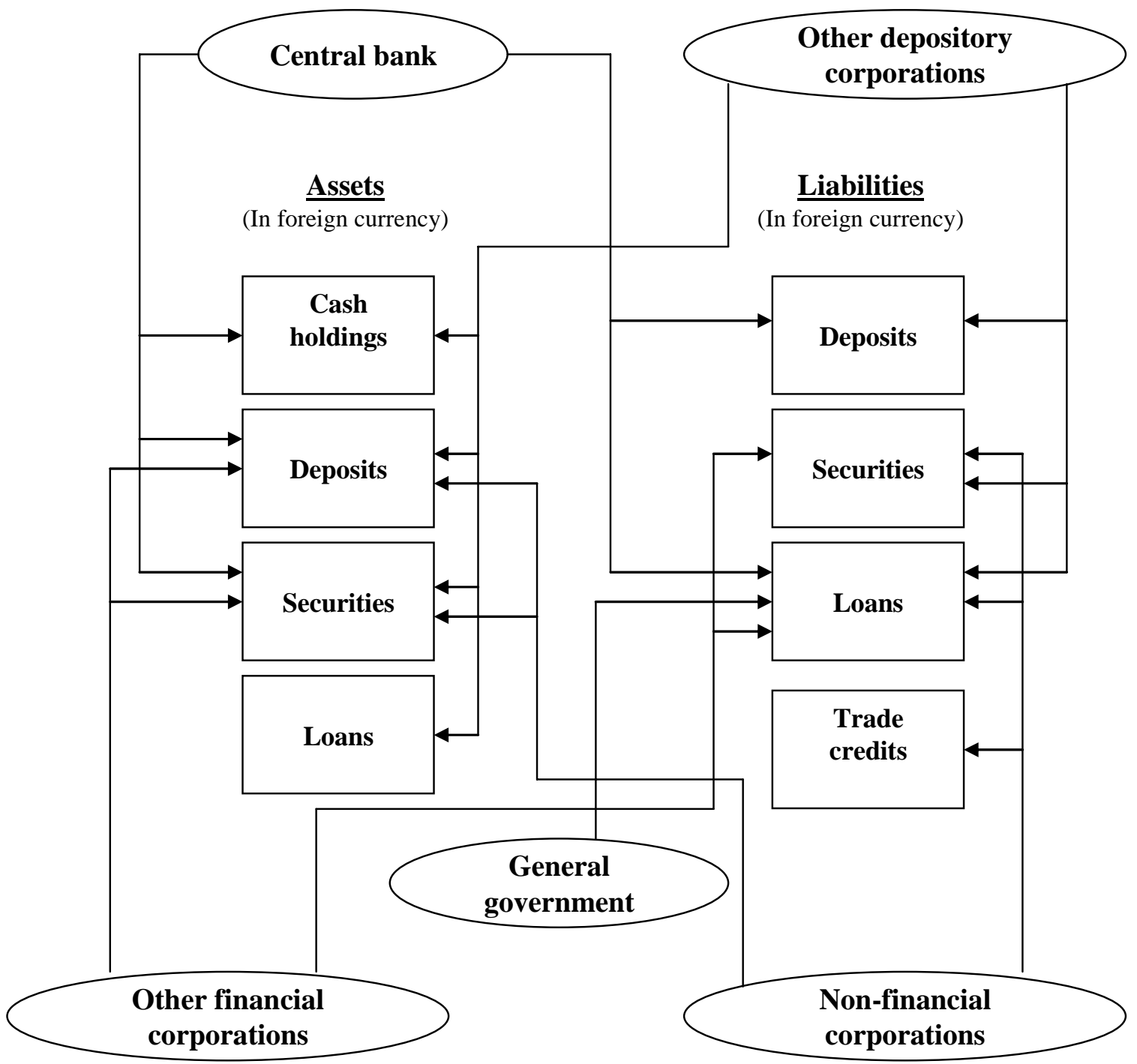

\section{Data methodologies and availability for balance sheet analysis}

Recent improvements in statistical methodologies and data availability are enhancing the potential for detecting and monitoring macroeconomic balance sheet vulnerabilities. In particular, some of the datasets introduced in recent years permit a much more frequent, detailed, and up-to-date analysis.

These databases are compiled according to particular statistical methodologies, which themselves are evolving partly due to the requirements of greater stock-based analysis. This chapter discusses these methodologies and datasets, and illustrates their usefulness in terms of meeting the data requirements for the BSA. 


\section{A. Relationship between the BSA and 1993 SNA methodologies and datasets}

The 1993 SNA is the internationally-agreed upon integrated set of production, income, accumulation, and financial accounts, balance sheets, and supporting tables that describe all economic flows and stocks of assets and liabilities in an economy, with full reconciliation of flows and stocks. As such, the BSA framework is a component of the 1993 SNA and is grounded in its methodology for defining transactions, institutions, sectors of the economy, classifications of assets and liabilities, and accounting rules. In addition, the 1993 SNA provides the framework and methodology for the main sectors of an economy. Specific methodologies for these main sectors and their databases have drawn on the 1993 SNA, but have adopted definitions of sectors and classifications of assets and liabilities that may differ in some respects (Box 2). The BSA can draw on the many sectoral methodologies based on the 1993 SNA.

\[ \begin{array}{l}\text { Box } 2 \\ \text { Relevant data methodologies }\end{array} \]
Monetary and Financial Statistics Manual (MFSM) and Standardized Report Forms (SRFs);
Compilation Guide on Financial Soundness Indicators (FSIs);
Balance of Payments Manual, Fifth Edition (BPM5);
External Debt Statistics: Guide for Compilers and Users (External Debt Guide);
International Investment Position: A Guide to Data Sources (IIP);
Coordinated Portfolio Investment Survey, Second Edition, (CPIS);
International Reserves and Foreign Currency Liquidity, Guidelines for a Data Template (Reserves
Template); and
Government Finance Statistics Manual 2001 (GFSM 2001).

The 1993 SNA sequence of accounts applies in principle to any institution or sector. If the BSA is narrowed to examine the vulnerabilities of a particular sector known to be problematic - for example, the financial sector and its potential to trigger a macroeconomic crisis - then the balance sheet for that sector provides the framework for the BSA. Even in the case of applying the BSA to one sector, balance sheets for other sectors can be useful for crosschecking or filling in data missing in the balance sheet of the sector under examination.

\section{B. Potential databases for the BSA}

Databases based on methodologies relevant for the BSA are potential sources of data for its application. The BSA can be applied to an individual country or for cross-country analysis of vulnerability using information from statistical databases for the 1993 SNA and its major component systems. These include monetary and financial statistics, in particular, and the SRFs data, balance of payments, IIP, QEDS, CPIS, and government finance statistics. Nearly all entries in the $7 \times 7$ intersectoral framework for the BSA can be filled using data from the SRFs, IIP, QEDS, and CPIS (Table 4).

\section{Financial sector}

The MFSM provides the guidelines on statistical methodology presenting monetary and financial statistics. The methodology set out in MFSM is harmonized with the 1993 SNA, but does not prescribe the detail on currency and maturity required for the BSA. 
Table 4

Potential data sources for estimating intersectoral asset and liability matrix

\begin{tabular}{|c|c|c|c|c|c|c|c|}
\hline $\begin{array}{c}\text { Holder of } \\
\text { Liability } \\
\text { (creditor) }\end{array}$ & Central bank & $\begin{array}{c}\text { General } \\
\text { government }\end{array}$ & $\begin{array}{l}\text { Other depository } \\
\text { corporations }\end{array}$ & $\begin{array}{c}\text { Other financial } \\
\text { corporations }\end{array}$ & $\begin{array}{l}\text { Non-financial } \\
\text { corporations }\end{array}$ & $\begin{array}{l}\text { Other resident } \\
\text { sector }\end{array}$ & Non-residents \\
\hline Central bank & & $\begin{array}{l}\text { 1. SRF 1SR } \\
\text { (Liabilities) }\end{array}$ & $\begin{array}{l}\text { 1. SRF 1SR } \\
\text { (Liabilities) } \\
\text { 2. SRF 2SR } \\
\text { (Assets) }\end{array}$ & $\begin{array}{l}\text { 1. SRF 1SR } \\
\text { (Liabilities) }\end{array}$ & $\begin{array}{l}\text { 1. SRF 1SR } \\
\text { (Liabilities) }\end{array}$ & $\begin{array}{l}\text { 1. SRF 1SR } \\
\text { (Liabilities) }\end{array}$ & $\begin{array}{l}\text { 1. SRF 1SR } \\
\text { (Liabilities) } \\
\text { 2. IIP } \\
\text { 3. JEDH }\end{array}$ \\
\hline $\begin{array}{l}\text { General } \\
\text { government }\end{array}$ & $\begin{array}{l}\text { 1. SRF 1SR } \\
\text { (Assets) }\end{array}$ & & $\begin{array}{l}\text { 1. SRF 2SR } \\
\text { (Assets) }\end{array}$ & $\begin{array}{l}\text { 1. SRF 4SR } \\
\text { (Assets) }\end{array}$ & n.a. & n.a. & $\begin{array}{l}\text { 1. IIP } \\
\text { 2. QEDS }\end{array}$ \\
\hline $\begin{array}{l}\text { Other depository } \\
\text { corporations }\end{array}$ & $\begin{array}{l}\text { 1. SRF 1SR } \\
\text { (Assets) } \\
\text { 2. SRF 2SR } \\
\text { (Liabilities) }\end{array}$ & $\begin{array}{l}\text { 1. SRF 2SR } \\
\text { (Liabilities) }\end{array}$ & & $\begin{array}{l}\text { 1. SRF 2SR } \\
\text { (Liabilities) }\end{array}$ & $\begin{array}{l}\text { 1. SRF 2SR } \\
\text { (Liabilities) }\end{array}$ & $\begin{array}{l}\text { 1. SRF 2SR } \\
\text { (Liabilities) }\end{array}$ & $\begin{array}{l}\text { 1. SRF 2SR } \\
\text { (Liabilities) } \\
\text { 2. IIP } \\
\text { 3. QEDS }\end{array}$ \\
\hline $\begin{array}{l}\text { Other financial } \\
\text { corporations }\end{array}$ & $\begin{array}{l}\text { 1. SRF 1SR } \\
\text { (Assets) }\end{array}$ & $\begin{array}{c}\text { 1. SRF 4SR } \\
\text { (Liabilities) }\end{array}$ & $\begin{array}{l}\text { 1. SRF 2SR } \\
\text { (Assets) }\end{array}$ & & $\begin{array}{l}\text { 1. SRF 4SR } \\
\text { (Liabilities) }\end{array}$ & $\begin{array}{c}\text { 1. SRF 4SR } \\
\text { (Liabilities) }\end{array}$ & $\begin{array}{l}\text { 1. SRF 4SR } \\
\text { (Liabilities) } \\
\text { 2. IIP } \\
\text { 3. QEDS }\end{array}$ \\
\hline $\begin{array}{l}\text { Non-financial } \\
\text { corporations }\end{array}$ & $\begin{array}{l}\text { 1. SRF 1SR } \\
\text { (Assets) }\end{array}$ & n.a. ${ }^{1}$ & $\begin{array}{l}\text { 1. SRF 2SR } \\
\text { (Assets) }\end{array}$ & $\begin{array}{l}\text { 1. SRF 4SR } \\
\text { (Assets) }\end{array}$ & & n.a. & $\begin{array}{l}\text { 1. IIP } \\
\text { 2. QEDS } \\
\text { 3. JEDH }\end{array}$ \\
\hline $\begin{array}{l}\text { Other resident } \\
\text { sectors }\end{array}$ & $\begin{array}{l}\text { 1. SRF 1SR } \\
\text { (Assets) }\end{array}$ & n.a. ${ }^{1}$ & $\begin{array}{l}\text { 1. SRF 2SR } \\
\text { (Assets) }\end{array}$ & $\begin{array}{l}\text { 1. SRF 4SR } \\
\text { (Assets) }\end{array}$ & n.a. & & $\begin{array}{l}\text { 1. IIP } \\
\text { 2. CPIS }{ }^{2}\end{array}$ \\
\hline Non-residents & $\begin{array}{l}\text { 1. SRF 1SR } \\
\text { (Assets) } \\
\text { 2. IIP } \\
\text { 3. CPIS }\end{array}$ & $\begin{array}{l}\text { 1. IIP } \\
\text { 2. CPIS }\end{array}$ & $\begin{array}{l}\text { 1. SRF 2SR } \\
\text { (Assets) } \\
\text { 2. IIP } \\
\text { 3. CPIS }\end{array}$ & $\begin{array}{l}\text { 1. SRF 4SR } \\
\text { (Assets) } \\
\text { 2. IIP } \\
\text { 3. CPIS }\end{array}$ & $\begin{array}{l}\text { 1. IIP } \\
\text { 2. CPIS }\end{array}$ & $\begin{array}{l}\text { 1. IIP } \\
\text { 2. CPIS }\end{array}$ & \\
\hline
\end{tabular}

${ }^{1}$ This data gap can in the future be filled with data from the public debt data template (which also covers assets) which is being piloted in some countries

CPIS data aca 
Table 5

Uses of Standardized Report Form (SRF) data to estimate intersectoral asset and liability positions

\begin{tabular}{|c|c|c|c|c|c|c|c|}
\hline $\begin{array}{l}\text { Holder of } \\
\text { liability } \\
\text { (Creditor) }\end{array}$ & Central bank & $\begin{array}{c}\text { General } \\
\text { government }\end{array}$ & $\begin{array}{l}\text { Other depository } \\
\text { corporations }\end{array}$ & $\begin{array}{l}\text { Other financial } \\
\text { corporations }\end{array}$ & $\begin{array}{l}\text { Non-financial } \\
\text { corporations }\end{array}$ & $\begin{array}{l}\text { Other resident } \\
\text { sector }\end{array}$ & Non-residents \\
\hline Central bank & & & 2 & & $\begin{array}{l}\text { Central bank } \\
\text { liabilities } \\
\text { (SRF 1SR) }\end{array}$ & & \\
\hline $\begin{array}{l}\text { General } \\
\text { government }\end{array}$ & & & & & & & \\
\hline $\begin{array}{l}\text { Other depository } \\
\text { corporations }\end{array}$ & & & & & $\begin{array}{c}\text { Other depository } \\
\text { corporations liabilitie } \\
\text { (SRF 2SR) }\end{array}$ & & \\
\hline $\begin{array}{l}\text { Other financial } \\
\text { corporations }\end{array}$ & & & & & $\begin{array}{l}\text { Other financial } \\
\text { corporations liabilities } \\
\text { (SRF 4SR) }\end{array}$ & & \\
\hline $\begin{array}{l}\text { Non-financial } \\
\text { corporations }\end{array}$ & $\begin{array}{l}\text { Central bank } \\
\text { assets } \\
\text { (SRF 1SR) }\end{array}$ & & $\begin{array}{c}\text { Other } \\
\text { depository } \\
\text { corporations } \\
\text { assets } \\
\text { (SRF 2SR) } \\
\end{array}$ & $\begin{array}{l}\text { Other financial } \\
\text { corporations } \\
\text { assets } \\
\text { (SRF 4SR) }\end{array}$ & & & \\
\hline $\begin{array}{l}\text { Other resident } \\
\text { sectors }\end{array}$ & & & & & & & \\
\hline Non-residents & & & & & & & \\
\hline
\end{tabular}


The introduction in 2005 of the SRFs for monetary and financial sector data fills an important gap in data coverage for the BSA. The SRFs are based on sectoral balance sheets for the central bank (report form 1SR), other depository corporations (report form 2SR), and other financial corporations (report form 4SR), as defined in the MFSM. They provide the required breakdown by domestic and foreign currency as well as information on the maturity structure, sometimes indirectly, ${ }^{17}$ for both domestic and external assets and liabilities, as well as the required decomposition by domestic sectors. For countries submitting SRFs, the BSA template can be populated with a high level of detail to provide an up-to-date analysis comparable across countries.

The new SRF data can provide the information needed to fill in a majority of entries in the $7 \times 7$ intersectoral framework for the BSA (Table 5). For entries where the assets and liabilities overlap for the central bank, other depository corporations, and other financial corporations, the assets reported by sector should match the corresponding liabilities reported by the other. This is not always the case and the analyst has to decide which information is more accurate. (Gulde and others 2003). Generally, data reported by the central bank are taken to be more reliable than that reported by other depository corporations, and by these two sectors more reliable than by other financial corporations.

Given that the SRF data are standardized across countries, the method of estimating intersectoral relationships based on SRF data can be replicated for other countries. The mapping of SRF variables into the BSA framework can be followed for all countries. ${ }^{18}$ For remaining intersectoral relationships, other data sources, such as QEDS and CPIS, can be used.

The SRF submission for South Africa illustrates the usefulness of these new data for conducting up-to-date monthly analysis of balance sheet vulnerabilities. The monthly SRF data have been combined with data from the QEDS and CPIS in the BSA framework to estimate detailed intersectoral positions, by financial instrument and currency (Table 2). The framework also allows for a breakdown by claims and liabilities, which can be very useful when analyzing net financial positions.

Clearly one of the greatest advantages of this approach is that detailed monthly intersectoral positions can be estimated by financial instrument and by currency, permitting a detailed analysis of changes in macroeconomic vulnerability in an integrated framework over time (Figure 4). The sectoral position can also be investigated vis-à-vis a particular sector (Figure 5). Once a particular vulnerability is identified, any change can be analyzed in detail, including by currency, type of claim, and financial instrument (Figure 6).

The compilation of financial sector indicators supports the BSA. Based on the Compilation Guide on Financial Soundness Indicators (IMF, 2004c), 62 countries are making a concentrated and coordinated effort to compile financial sector indicators and publish results by the end of 2006. The financial sector indicator data, particularly data for the key nonfinancial sectors covered, will usefully support and complement BSA applications. In particular, the cross-border consolidated data underlying the financial sector indicators cover complex banking systems with significant foreign subsidiary and branch networks that may not be adequately covered in the BSA framework.

17 The maturity structure can be derived by defining financial assets that are not included in broad money as long term. However, this classification might be inappropriate in a particular country; in those cases the SRF data should be complemented by, for example, information on the maturity structure of government securities.

18 This mapping assigns the SRF variable codes standardized across countries to their appropriate cells in the $7 \times 7$ intersectoral framework for the BSA. 
Figure 4

South Africa: sectoral net financial positions, by currency

In percent of GDP, December 2003-November 2005
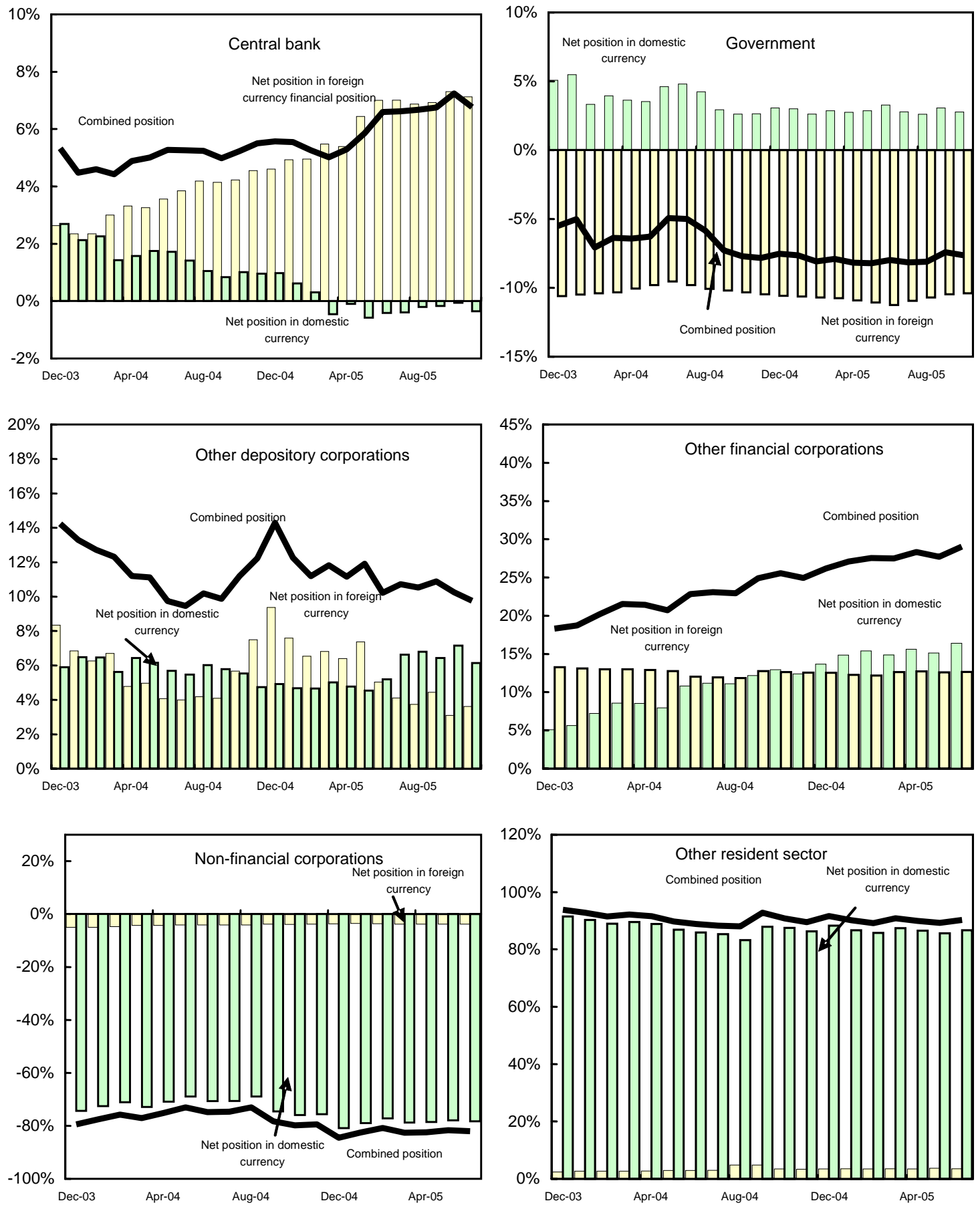

Note: Sectorial net financial positions represented in figure are total financial assets minus total financial liabilities.

Sources: Standardized report forms; joint external debt hub; coordinated portofolio investment survey; and quarterly external debt statistics. 
Figure 5

South Africa: sectoral net financial positions vis-à-vis non-residents, by currency

In percent of GDP, December 2003-November 2005
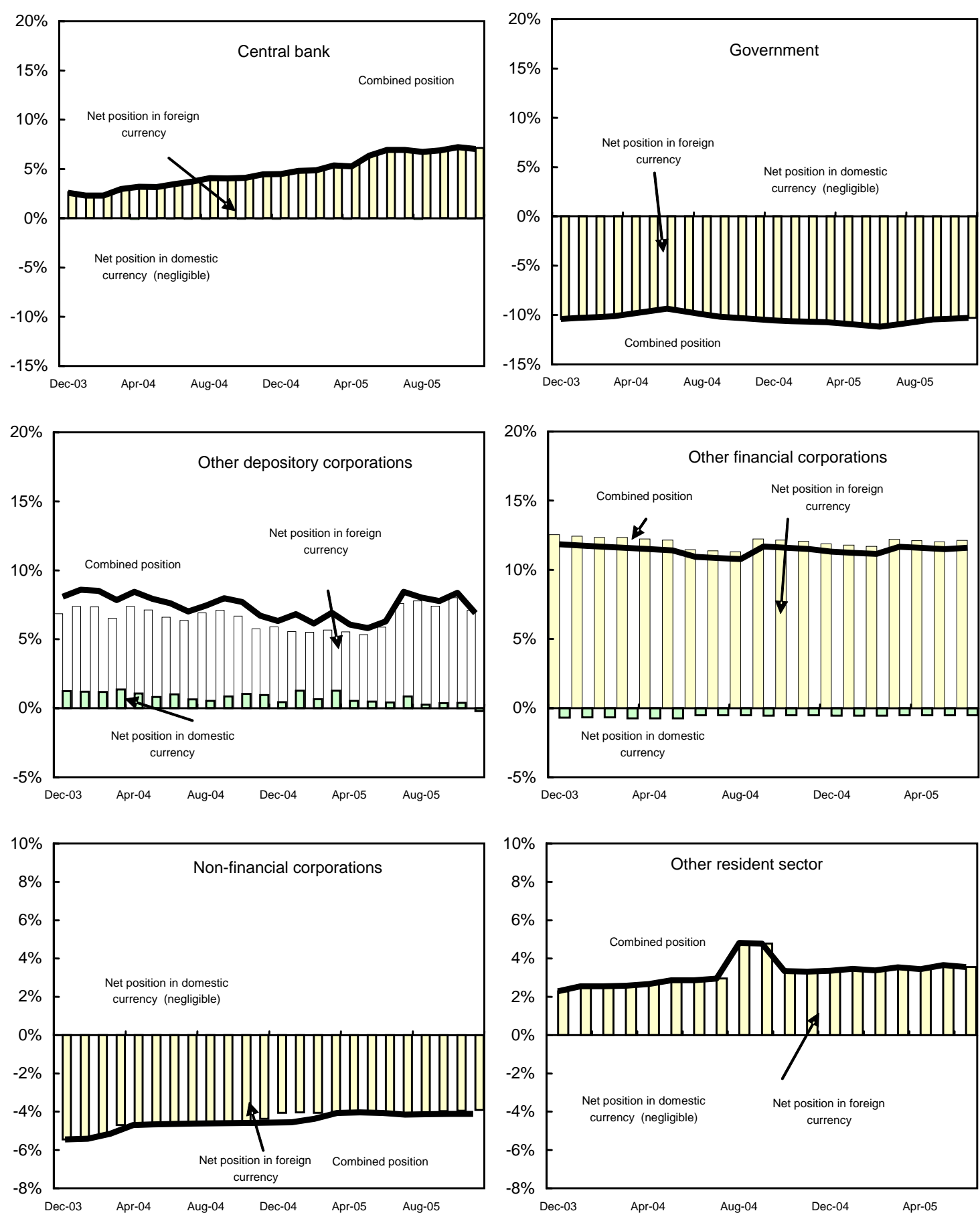

Note: Sectorial net financial positions represented in figure are total financial assets minus total financial liabilities.

Sources: Standardized report forms; joint external debt hub; coordinated portofolio investment survey; and quarterly external debt statistics. 
Figure 6

South Africa: other depository corporations detailed positions vis-à-vis non-residents, by currency and instrument

In percent of GDP, December 2003-November 2005
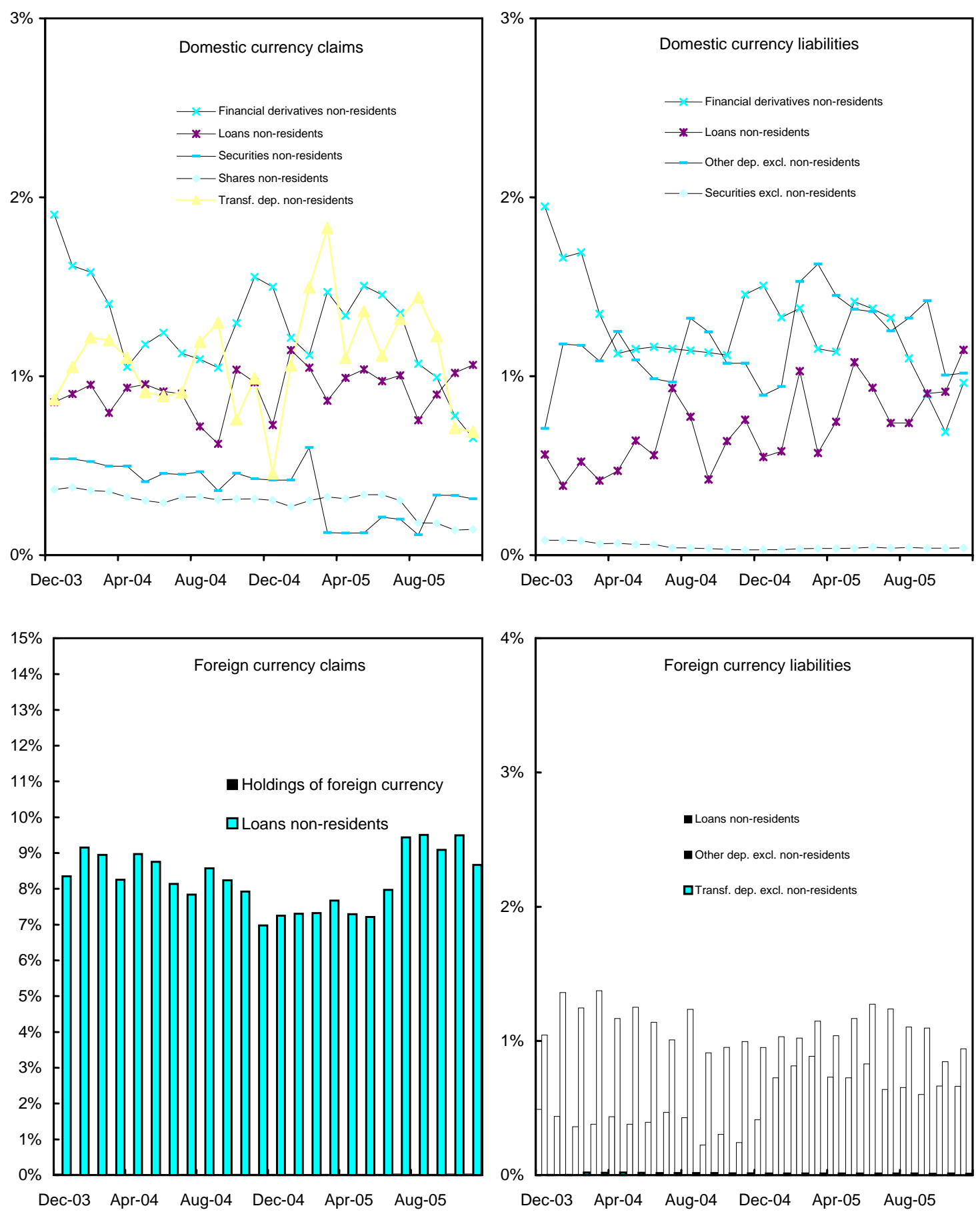

Source: Standardized Report Forms. 


\section{External sector}

The balance of payments accounts and IIP and QEDS data are closely linked to the 1993 SNA. This linkage is reinforced by the fact that, in almost all countries, balance of payments, external debt, and IIP data are first compiled and subsequently incorporated into national accounts. Although the Fifth Edition of the Balance of Payments Manual (known as BPM5) (IMF, 1993b) does not explicitly call for a currency breakdown, this is not necessarily a serious problem for assets, as for nearly all countries the vast majority of external assets are denominated in foreign currency. IIP and QEDS data present a short- and long-term maturity breakdown on an original maturity basis consistent with the 1993 SNA.

The introduction in 2004 of the online QEDS dataset, based on the External Debt Statistics: Guide for Compilers and Users (IMF, 2003), provides information on external liabilities with breakdowns by currency and maturity that can be used in the BSA framework. It is maintained by the World Bank and updated within one month after the end of each quarter. Breakdowns include short- and long-term maturity of debt based on original maturity, and financial instruments (currency, deposits, money market instruments, bonds and notes, loans, trade credits, other debt liabilities). QEDS also includes information on a remaining maturity basis. The online dataset brings together in a central location detailed quarterly external debt data from 55 of the 62 countries currently subscribing to the SDDS. ${ }^{19}$ It facilitates both time-series analysis and cross-country data comparisons.

The joint external debt hub brings together external debt data for about 175 countries that are available from the BIS, IMF, OECD, and World Bank, including national external debt data for most SDDS subscribers. Data on selected external debt components (long- and short-term maturities), including bank loans, official bilateral loans, debt securities issued abroad and non-bank trade credits, are disseminated on a quarterly basis. The database complements external debt statistics based on national sources, filling important coverage gaps, particularly in the area of private sector external liabilities.

The IMF's Data Template on International Reserves and Foreign Currency Liquidity provides a consistent framework for assessing a country's official foreign currency liquidity position on a comprehensive and timely basis. It facilitates the disclosure of information on international reserve assets together with information on potential short-term foreign currency obligations (and claims) that affect the analysis of international reserve assets, including off-balance sheet activities (such as those arising from forwards, futures, and other financial derivatives operations). The institutional coverage applies to monetary authorities and the central government, and foreign currency flows are related to both residents and non-residents.

The IIP has been a useful data source for the BSA. The IIP presents data on a country's external financial position, with the primary focus on the stock of financial assets and liabilities. Data items include financial claims on and liabilities to non-residents, equity assets and liabilities, financial derivative instruments, monetary gold, and special drawing rights (SDRs). The liability component of the IIP data is closely related to QEDS. ${ }^{20}$

19 The availability of QEDS data is expected to expand in the near future. The number of potential countries covered by the database increases with the number of SDDS subscribers. Also, coverage is expected to improve, as SDDS countries are increasing the number of tables of the QEDS for which data are provided, with an emphasis on currency and maturity breakdown. Finally, some non-SDDS countries are expected in the near future to be able to prepare, at least, the SDDS prescribed external debt data category.

20 The IIP includes some non-financial assets whose ownership is construed by convention as ownership of financial assets, owing to its definition as a financial claim of a non-resident on a resident entity that is considered the owner of the asset, as for example in the case of ownership of immovable assets such as land (IMF, 1993, paragraph 316). 
The CPIS can complement the datasets above by providing survey data on cross-border holdings of securities (equities, long- and short-term debt) by counterpart jurisdiction of issuer. The CPIS is an annual survey of portfolio investment assets for 71 countries based on a methodology drawn from the BPM5. The CPIS has been undertaken on an annual basis since 2001, but data are also available for the 1997 CPIS. The CPIS collects comprehensive information on the stock of cross-border holdings of equities and short- and long-term debt securities valued at market prices and broken down by the economy of residence of the issuer. This global database includes data on reported cross-border holdings of securities and derived portfolio investment liabilities with the capacity for showing bilateral and partner economy data from the creditor or debtor perspective. The CPIS is a useful data source for estimating intersectoral asset and liability positions with non-residents both directly and through derived counterparty country information. It contains some information on the sector of holder and currency of issue, but lacks the necessary breakdown on sectoral liabilities to non-residents. The data are available with a lag of one year or more.

\section{Public sector}

Introduction of the Government Finance Statistics Manual (known as GFSM 2001) (IMF, 2001b) represented a significant step toward the presentation of general government statistics in a manner consistent with the BSA. An innovation of the GFSM 2001 was the integration of a balance sheet in the framework for public sector statistics. As prescribed by the 1993 SNA, this balance sheet integrates transactions and other economic flows with stocks of assets and liabilities. It is similar to balance sheets for other sectors, thereby facilitating intersectoral comparisons.

\section{Data availability}

Data availability for a high frequency and up-to date country balance sheet approach is improving. Currently, more than 40 countries, including most emerging market countries, have the required data coverage for the detailed BSA framework presented in this paper (Table 6). Clearly, the main improvement is the recently-introduced SRFs for monetary and financial sector data, which provide the vast majority of the required intersectoral balance. Moreover, the key advantage of these datasets - which so far encompass 72 countries - is that they are compiled monthly and with a high level of detail standardized across countries. The remaining gaps on government and non-financial corporations' liabilities to non-residents can be closed by the online QEDS introduced in 2004, which is available for 55 countries. IIP data - currently available for more than 100 countries - can be used to fill the remaining gaps on sectoral positions vis-à-vis non-residents. In cases where IIP data are not available, JEDH data can fill in some of the gaps, particularly for non-financial domestic sector liabilities to non-residents, and the CPIS provides information on domestic sector claims on nonresidents, albeit with a substantial lag and on an annual frequency. However, the government liabilities to the non-financial domestic sectors are generally not readily available, nor are government claims on the non-financial domestic sectors or non-financial domestic sector holdings of claims on government, although the latter two gaps generally are considered to be minor. ${ }^{21}$

21 These gaps are expected to be closed by the public debt template, which covers detailed sectoral claims of and liabilities to government. 
Table 6

Available datasets for balance sheet vulnerability analysis as of Nov. 2006

\begin{tabular}{|c|c|c|c|c|c|}
\hline Countries & $\begin{array}{l}\text { Standard- } \\
\text { ized } \\
\text { report } \\
\text { forms }\end{array}$ & $\begin{array}{c}\text { Quarterly } \\
\text { external } \\
\text { debt } \\
\text { statistics }\end{array}$ & $\begin{array}{l}\text { Interna- } \\
\text { tional } \\
\text { invest- } \\
\text { ment } \\
\text { position } \\
\text { data }\end{array}$ & $\begin{array}{c}\text { Coordi- } \\
\text { nated } \\
\text { portfolio } \\
\text { investment } \\
\text { survey } \\
\text { data }\end{array}$ & $\begin{array}{c}\text { Joint } \\
\text { external } \\
\text { debt hub }\end{array}$ \\
\hline Albania & $x$ & & & & $\mathrm{x}$ \\
\hline Algeria $^{2}$ & & & & & $x$ \\
\hline Argentina $^{1}$ & & $x$ & $x$ & $x$ & $\mathrm{x}$ \\
\hline Armenia $^{2}$ & $X$ & $x$ & $\mathrm{x}$ & & $\mathrm{x}$ \\
\hline Azerbaijan $^{2}$ & & & $x$ & & $x$ \\
\hline Bahamas, The ${ }^{1}$ & & & & $x$ & $\mathrm{x}$ \\
\hline Bangladesh $^{1}$ & & & $x$ & & $x$ \\
\hline Belarus & $x$ & $x$ & $\mathrm{x}$ & & $x$ \\
\hline Belize & $\mathrm{x}$ & & & & $\mathrm{x}$ \\
\hline Bhutan & $x$ & & & & $x$ \\
\hline Bolivia $^{1}$ & & & $\mathrm{x}$ & & $x$ \\
\hline Botswana & $x$ & & $x$ & & $x$ \\
\hline Bulgaria & EAP & & $\mathrm{x}$ & $\mathrm{x}$ & $\mathrm{x}$ \\
\hline Burundi $^{1}$ & & & $\mathrm{x}$ & & $\mathrm{x}$ \\
\hline Cambodia $^{2}$ & & & $x$ & & $\mathrm{x}$ \\
\hline Canada & $x$ & $\mathrm{x}$ & $x$ & $x$ & $x$ \\
\hline Chile & $x$ & $x$ & $x$ & $x$ & $x$ \\
\hline China, P.R.: Macao ${ }^{1}$ & & & & $x$ & $x$ \\
\hline Costa Rica $^{1}$ & & $x$ & $x$ & $\mathrm{x}$ & $\mathrm{x}$ \\
\hline Croatia $^{2}$ & & $\mathrm{x}$ & $\mathrm{x}$ & & $\mathrm{x}$ \\
\hline Czech Republic & EAP & $x$ & $x$ & $x$ & $x$ \\
\hline Denmark & EAP & $x$ & $x$ & $x$ & $x$ \\
\hline Eastern Caribbean Currency Union & $x$ & & & & \\
\hline Anguilla & $\mathrm{x}$ & & & & \\
\hline Antigua \& Barbuda & $x$ & & & & \\
\hline Dominica & $x$ & & & & $x$ \\
\hline Grenada & $x$ & & & & $x$ \\
\hline Montserrat & $x$ & & & & \\
\hline St. Kitts \& Nevis & $\mathrm{x}$ & & & & $x$ \\
\hline St. Lucia & $x$ & & & & $x$ \\
\hline St. Vincent \& the Grenadines & $\mathrm{x}$ & & & & $\mathrm{x}$ \\
\hline
\end{tabular}

For footnotes, see the end of the table. 
Table 6 (cont)

Available datasets for balance sheet vulnerability analysis as of Nov. 2006

\begin{tabular}{|c|c|c|c|c|c|}
\hline Countries & $\begin{array}{l}\text { Standard- } \\
\text { ized } \\
\text { report } \\
\text { forms }\end{array}$ & $\begin{array}{c}\text { Quarterly } \\
\text { external } \\
\text { debt } \\
\text { statistics }\end{array}$ & $\begin{array}{l}\text { Interna- } \\
\text { tional } \\
\text { invest- } \\
\text { ment } \\
\text { position } \\
\text { data }\end{array}$ & $\begin{array}{c}\text { Coordi- } \\
\text { nated } \\
\text { portfolio } \\
\text { investment } \\
\text { survey } \\
\text { data }\end{array}$ & $\begin{array}{c}\text { Joint } \\
\text { external } \\
\text { debt hub }\end{array}$ \\
\hline Ecuador & $x$ & $x$ & $x$ & & $x$ \\
\hline Egypt & $X$ & $x$ & & $X$ & $x$ \\
\hline El Salvador & $X$ & $x$ & $x$ & & $X$ \\
\hline Eritrea $^{2}$ & & & & & $x$ \\
\hline Estonia $^{1}$ & & $x$ & $x$ & $x$ & $x$ \\
\hline Ethiopia $^{1}$ & & & & & $x$ \\
\hline Euro Area & EAP & & & & \\
\hline Austria & EAP & $x$ & $x$ & $x$ & $x$ \\
\hline Belguim & EAP & $x$ & $x$ & $X$ & $X$ \\
\hline Finland & EAP & $x$ & $\mathrm{x}$ & $x$ & $x$ \\
\hline France & EAP & $x$ & $x$ & $X$ & $x$ \\
\hline Germany & EAP & $x$ & $x$ & $x$ & $x$ \\
\hline Greece & EAP & $x$ & X & $X$ & $X$ \\
\hline Ireland & EAP & $x$ & $X$ & $X$ & $X$ \\
\hline Italy & EAP & $x$ & $x$ & $x$ & $X$ \\
\hline Luxembourg & EAP & & $x$ & $x$ & $x$ \\
\hline Netherlands & EAP & $x$ & $x$ & $\mathrm{x}$ & $x$ \\
\hline Portugal & EAP & $x$ & $x$ & $x$ & $x$ \\
\hline Spain & EAP & $x$ & $x$ & $x$ & $x$ \\
\hline Georgia & $X$ & & & & $x$ \\
\hline Ghana $^{1}$ & & & & & $x$ \\
\hline Guatemala & $x$ & & & & $x$ \\
\hline Guyana & $x$ & & & & $x$ \\
\hline India ${ }^{2}$ & & & $x$ & $x$ & $x$ \\
\hline Indonesia & $X$ & & $X$ & $X$ & $X$ \\
\hline Kazakhstan & $x$ & $x$ & $x$ & $x$ & $x$ \\
\hline Kenya $^{1}$ & & & & & $x$ \\
\hline Korea $^{1}$ & & & $x$ & $x$ & $X$ \\
\hline Kuwait $^{1}$ & & & & & $X$ \\
\hline Kyrgyz Republic ${ }^{1}$ & & & $x$ & & $x$ \\
\hline Lesotho $^{2}$ & & & $x$ & & $x$ \\
\hline
\end{tabular}

For footnotes, see the end of the table. 
Table 6 (cont)

Available datasets for balance sheet vulnerability analysis as of Nov. 2006

\begin{tabular}{|c|c|c|c|c|c|}
\hline Countries & $\begin{array}{l}\text { Standard- } \\
\text { ized } \\
\text { report } \\
\text { forms }\end{array}$ & $\begin{array}{c}\text { Quarterly } \\
\text { external } \\
\text { debt } \\
\text { statistics }\end{array}$ & $\begin{array}{l}\text { Interna- } \\
\text { tional } \\
\text { invest- } \\
\text { ment } \\
\text { position } \\
\text { data }\end{array}$ & \begin{tabular}{|} 
Coordi- \\
nated \\
portfolio \\
investment \\
survey \\
data
\end{tabular} & $\begin{array}{c}\text { Joint } \\
\text { external } \\
\text { debt hub }\end{array}$ \\
\hline Malawi $^{1}$ & & & & & $X$ \\
\hline Malaysia & $x$ & $x$ & $x$ & $x$ & $x$ \\
\hline Malta $^{1}$ & & & $x$ & $X$ & $x$ \\
\hline Mauritius & $x$ & & $x$ & $x$ & $X$ \\
\hline Mexico & $x$ & $x$ & $x$ & $x$ & $x$ \\
\hline Moldova $^{2}$ & & $x$ & $x$ & & $x$ \\
\hline Mongolia $^{1}$ & & & & & $x$ \\
\hline Morocco $^{1}$ & & & $X$ & & $x$ \\
\hline Mozambique & $x$ & & $x$ & & $x$ \\
\hline Namibia & $X$ & & $x$ & & $x$ \\
\hline $\mathrm{Nepal}^{1}$ & & & & & $x$ \\
\hline Nicaragua & $x$ & & $x$ & & $x$ \\
\hline Pakistan $^{1}$ & & & $x$ & $x$ & $x$ \\
\hline Papua New Guinea & $x$ & & & & $x$ \\
\hline Paraguay $^{1}$ & & $X$ & $X$ & & $X$ \\
\hline Romania & $x$ & & $x$ & $x$ & $x$ \\
\hline Rwanda $^{1}$ & & & $x$ & & $x$ \\
\hline Serbia & $x$ & & & & $x$ \\
\hline Seychelles $^{2}$ & & & & & $x$ \\
\hline Slovak Republic & EAP & $x$ & $x$ & $x$ & $x$ \\
\hline South Africa & $x$ & $x$ & $x$ & $x$ & $x$ \\
\hline Sudan $^{1}$ & & & & & $x$ \\
\hline Suriname & $x$ & & & & $x$ \\
\hline Swaziland & $x$ & & $x$ & & $x$ \\
\hline Sweden & EAP & $x$ & $x$ & $x$ & $x$ \\
\hline Tanzania $^{1}$ & & & $x$ & & $x$ \\
\hline Thailand & $x$ & $x$ & $x$ & $x$ & $x$ \\
\hline Tonga $^{2}$ & & & & & $x$ \\
\hline Tunisia $^{1}$ & & $x$ & $x$ & & $x$ \\
\hline Turkey $^{1}$ & & $x$ & $x$ & $x$ & $x$ \\
\hline Uganda $^{1}$ & & & $x$ & & $X$ \\
\hline
\end{tabular}

For footnotes, see the end of the table. 
Table 6 (cont)

Available datasets for balance sheet vulnerability analysis as of Nov. 2006

\begin{tabular}{l|c|c|c|c|c}
\hline Countries & $\begin{array}{c}\text { Standard- } \\
\text { ized } \\
\text { report } \\
\text { forms }\end{array}$ & $\begin{array}{c}\text { Quarterly } \\
\text { external } \\
\text { debt } \\
\text { statistics }\end{array}$ & $\begin{array}{c}\text { Interna- } \\
\text { tional } \\
\text { invest- } \\
\text { ment } \\
\text { position } \\
\text { data }\end{array}$ & $\begin{array}{c}\text { Coordi- } \\
\text { nated } \\
\text { portfolio } \\
\text { investment } \\
\text { survey } \\
\text { data }\end{array}$ & $\begin{array}{c}\text { Joint } \\
\text { external } \\
\text { debt hub }\end{array}$ \\
\hline Ukraine & $X$ & $X$ & $X$ & $X$ & $X$ \\
United States $_{\text {Vanuatu }^{1}}$ & $X$ & $X$ & $X$ & & $X$ \\
Yemen $^{1}$ & & & $X$ & $X$ & $X$ \\
Zambia $^{\text {Zamia }}$ & $X$ & & $X$ & & $X$ \\
\hline
\end{tabular}

${ }^{1}$ SRF test data are being reviewed by IMF staff for quality. ${ }^{2}$ Approval of SRF test data is expected to be completed by Nov. 2006.

EAP = Euro Area Presentation of the SRFs.

An $\mathrm{X}$ for IIP simply indicates that IIP data is provided to STA. No distinction is made for completeness of reporting.

\section{Data reliability}

Balance sheet analysis should ideally be based on comprehensive and consistent financial statistics appropriately delineated by sector and financial instruments. However, two types of data deficiencies typically prevent a complete sectoral analysis: lack of appropriate data and multiple (or overlapping) data for a particular financial instrument, either intrasectoral or intersectoral. To minimize discrepancies and determine the extent to which any remaining data deficiencies might undermine the results of the analysis, data reliability can be assessed by sector and financial instrument. ${ }^{22}$

Data reliability can vary significantly by sector (Table 7). In general, central bank data are most reliable, followed by data from commercial banks and other financial corporations, international investment position data, and government debt data. Secondary trading in government debt can substantially affect the ability to determine sectoral holdings of government securities. Data on households and non-financial corporations are typically very scarce in emerging markets and in many cases are nonexistent. In these circumstances, two basic techniques - counterpart data collection and residual data collection - can be used to obtain data. As CPIS data are allocated by type of security and country of issuer, they represent a useful source for deriving counterpart data on all sectors, particularly households and non-financial corporations.

22 The data quality assessment framework (DQAF) for external debt statistics issued by the IMF's Statistics Department in June 2005 provides a useful tool to assess the quality of external debt statistics. The DQAF follows a comprehensive view of quality, which examines quality-related features of governance of statistical institutions, core statistical processes, and statistical outputs, and is intended to be applicable to any country. 
Table 7

Data reliability, by sector

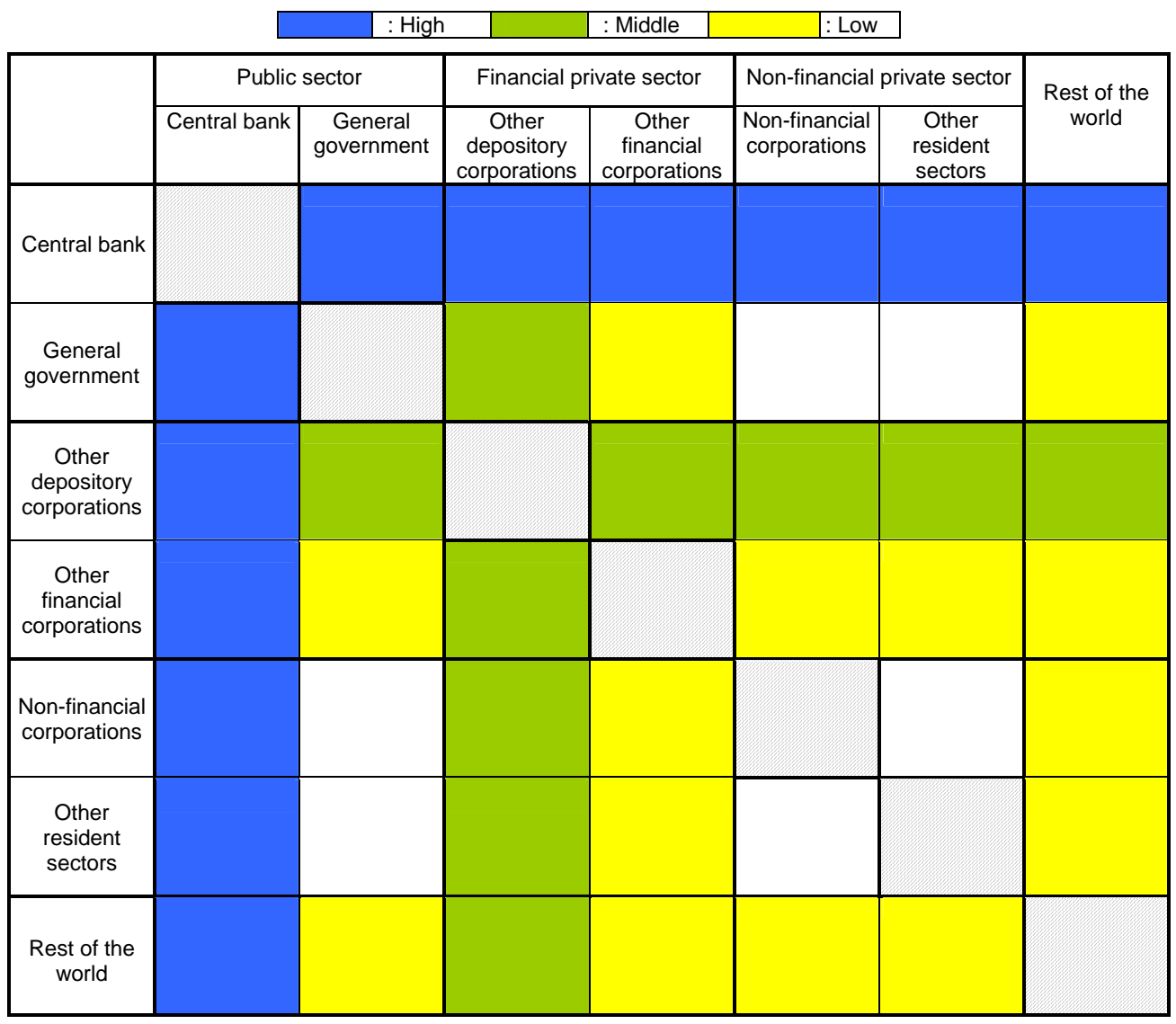

Sectoral data reliability can also vary by methodology. In general, the most reliable data are those that follow the MFSM (financial corporations), BPM5 (balance of payments data), International Investment Position: A Guide to Data Sources Guide (IMF, 2002), and the External Debt Statistics: Guide for Compilers and Users (such as QEDS) (IMF, 2003). Data on non-financial corporations' positions vis-à-vis household and non-profit organizations are generally less reliable. The uncertainly of these data is exacerbated if derived on a residual basis.

Data reliability also varies by financial instrument (Table 8). In general, the most reliable data are currency and deposits, loans, and securities (which together comprise the majority of SRF data). Also very reliable are external debt data on specific financial instruments, which can be obtained from both national sources (such as QEDS) and market and creditor sources (such as JEDH external debt and BIS international banking statistics). Estimates of trade credits and many types of government financial assets are often judged to be less reliable, but source data are still available on a sample basis or with a frequency that is less than quarterly or annually. The least reliable estimates are usually for miscellaneous assets and liabilities, which are commonly derived on a residual basis. 
Table 8

Data reliability, by financial instrument

\begin{tabular}{|c|c|c|c|c|c|c|c|c|c|c|c|c|c|c|}
\hline & \multicolumn{4}{|c|}{$\begin{array}{l}\text { Financial corporations } \\
\end{array}$} & \multirow{2}{*}{\multicolumn{2}{|c|}{$\begin{array}{l}\text { General } \\
\text { government }\end{array}$}} & \multicolumn{4}{|c|}{ Non-financial corporations } & & & & \\
\hline & \multicolumn{2}{|c|}{$\begin{array}{c}\text { Depository } \\
\text { corporations }\end{array}$} & \multicolumn{2}{|c|}{$\begin{array}{c}\text { Other financial } \\
\text { corporations }\end{array}$} & & & \multicolumn{2}{|c|}{$\begin{array}{l}\text { Public non- } \\
\text { financial } \\
\text { corporations }\end{array}$} & \multicolumn{2}{|c|}{$\begin{array}{l}\text { Other non- } \\
\text { financial } \\
\text { corporations }\end{array}$} & \multicolumn{2}{|c|}{ Other residents } & \multicolumn{2}{|c|}{$\begin{array}{l}\text { Rest of the } \\
\text { world }\end{array}$} \\
\hline & Asset & Liability & Asset & Liability & Asset & Liability & Asset & Liability & Asset & Liability & Asset & Liability & Asset & Liability \\
\hline \multicolumn{15}{|c|}{ Currency and deposits } \\
\hline \multicolumn{15}{|c|}{ Currency and deposits } \\
\hline \multicolumn{15}{|l|}{ Deposits } \\
\hline \multicolumn{15}{|l|}{ Loans } \\
\hline \multicolumn{15}{|c|}{ Securities other than shares } \\
\hline \multicolumn{15}{|c|}{ General government securities } \\
\hline \multicolumn{15}{|l|}{ Other securities } \\
\hline \multicolumn{15}{|c|}{ Structured-financing instruments } \\
\hline \multicolumn{15}{|c|}{ Shares and other equities } \\
\hline \multicolumn{15}{|c|}{ Financial derivatives } \\
\hline \multicolumn{15}{|c|}{ Insurance technical reserves } \\
\hline Other accounts & & & & & & & & & & & & & & \\
\hline
\end{tabular}

Note: The darker areas indicate where the compiler placed a relatively "high" degree of reliability. The moderately shaded areas indicate series where estimates are judged to be less reliable, but still where source data are available on a sample basis or on a basis where the frequency is less than quarterly or annually. The lightly shaded areas are for series where there is virtually no source data; estimates for series in the non shaded area are based largely on residual calculation.

Source: IMF, Compilation Guide for Monetary and Financial Statistics, Chapter 8 (forthcoming).

Aggregating sectoral data sets to undertake a balance sheet analysis of intersectoral relationships poses special challenges. As noted above, sometimes estimates for a particular subsector (eg, households) or a group of financial instruments (eg, miscellaneous assets/liabilities) have been derived using a residual calculation (this subsector or category of financial instrument is often referred to as a balancing item). These estimates therefore might include substantial discrepancies resulting from imprecise (or missing) data, which, when aggregated, could be magnified.

Caution is therefore required when handling economy-wide datasets, as there is a significant risk that unreliable estimates might undermine the results of the balance sheet analysis. The sectoral discrepancies hidden in the balancing item contain potentially valuable information on the size of the statistical error. The balance sheet analysis should therefore acknowledge these weaknesses and, if judged to be substantial, focus on sectoral relationships that are less affected by imprecise data or stress the caveats for using the data. 


\section{Using timely and frequent balance sheet analysis in surveillance}

The most important aspect of the new datasets is that they permit tracking the evolution of balance sheet vulnerabilities - the potential for liquidity or solvency problems - on a regular and timely basis for surveillance purposes. As the above example of South Africa illustrates, the new datasets - particularly the SRF, JEDH, QEDS, and CPIS - provide financial data with greater periodicity, detail, and timeliness, enabling better tracking of current vulnerabilities using the BSA. These data can be mapped into the $7 \times 7$ BSA framework for a monthly analysis of sectoral vulnerabilities. If needed, the framework also allows for a detailed breakdown by assets and liabilities by currency, which can be very useful when analyzing particular vulnerabilities. Recent applications of the BSA using these new databases illustrate some of the advantages for IMF surveillance. However, the full potential for detailed examination of a country's vulnerabilities and cross-country analysis based on comparable data will be realized in future applications of the BSA using these databases.

The recent BSA analysis for Belize (Mathisen and Torres, 2005) illustrates some of the usefulness of employing the new data in surveillance. The SRF data comprising the balance sheets of the central bank, commercial banks, and other financial corporations were combined with JEDH and QEDS data to analyze how vulnerabilities have been developing in that country. This analysis shows how the sharp increase in external public and publicly guaranteed debt - appearing as a major currency mismatch in the balance sheet analysis - is emerging as a maturity mismatch, with this debt increasingly rolled over on more costly, shorter terms. The balance sheet analysis also shows that a macroeconomic policy response is constrained, as external obligations derive mainly from the central government's external short-term debt and non-resident deposits. Consequently, a loss of the fixed exchange regime could exacerbate the government's solvency position, which could have systemic repercussions for the entire economy. If the emergence of these vulnerabilities had been monitored closely at an early stage, the range of remedial options would probably have been much larger.

The new datasets permit a closer integration of the BSA into surveillance activities, for example by discussing how a particular a country is coping with such risks. Applying the BSA to Georgia on a monthly basis using databases listed in Table 4, in particular the SRF data, supplemented by country authorities' data on public debt, Billmeier and Mathisen (2006) show how the overall level of vulnerability to currency mismatches has fallen recently, but sectoral trends vary. The high level of dollarization in Georgia creates sectoral currency mismatches and vulnerabilities to exchange rate shocks. Billmeier and Mathisen further describe how Georgia has pursued three main strategies for reducing vulnerabilities through the use of (1) buffers, primarily consisting of substantial foreign reserves in the banking system, as a general cushion against shocks; (2) hedges such as fixed interest debt mainly with long maturities, limits on banks' foreign positions, and the promotion of balancing income (such as remittances from abroad) with recurring foreign currency liabilities from abroad, primarily in the export sector; and (3) insurance against specific shocks through, for example, the IMF's shock facility.

The BSA based on the new datasets can be used as the basis for a dynamic, forwardlooking analysis of risks in sectoral balance sheets. In particular, the data collected for the BSA analysis provide a useful input into the calibration of the contingent claims approach (CCA) to measuring and analyzing such risks (Gapen and others, 2004). To assess risk fully, volatilities of key assets and other macroeconomic variables, as well as information from forward-looking prices where possible, need to be combined with balance sheet data to apply the CCA approach. Detailed data on the maturity and currency composition of various liabilities are necessary for determining the distress barriers in the CCA calibration modeling, supplemented with information on volatility, forward-looking prices, and other matters. Timely reserve information is also necessary. 
While helping to identify and track vulnerabilities in and among sectoral balance sheets, the CCA - being a dynamic framework for analyzing risk looking forward and computing probabilities of default - requires additional information and analytical modeling. It adapts widely-used finance and risk management tools to construct a marked-to-market balance sheet for the sovereign, financial, and corporate sectors and to derive a set of risk indicators that serve as a barometer of sovereign risk, financial sector vulnerability, and economy-wide risk. Using a structural model calibrated to a country's economy, the extent to which economic or financial shocks affect sovereign and sectoral balance sheets can be examined. This approach facilitates scenario and simulation analysis that permits assessment of potential market scenarios and estimation of probability distributions, spreads, and value-atrisk measures.

\section{Conclusions}

Delineation of sectors and financial instruments in a matrix of balance sheets for an economy is central to specifying the BSA framework for analysis of the potential for emerging liquidity or solvency problems. The sectorization and financial instruments in the $7 \times 7$ matrix presented in this paper provide a useful baseline for applying the BSA and can be adapted to focus on particular sectors to assess vulnerabilities in the economy. This framework can also be modified to accommodate data limitations and still be useful for vulnerability analysis.

Datasets introduced in recent years, combined with existing data sources, have contributed substantially to improved balance sheet data for macroeconomic vulnerability analysis. Until recently, data readily available from public sources, such as the IMF's International Financial Statistics or World Bank or BIS data bases, often had to be complemented, sometimes with great effort, by specially compiled datasets. The databases that have become available recently - particularly SRFS, IIP, QEDS, and CPIS - can reduce the need for special compilation in the future.

This paper used this approach for South Africa to complete the $7 \times 7$ intersectoral framework presented here. The sectorization and classification of financial instruments are sufficiently detailed to show the variation in intersectoral positions, by financial instrument and currency. In general, the method presented in this paper for populating the $7 \times 7$ matrix of balance sheets of the BSA framework can be replicated for other countries to capture vulnerabilities relevant for macroeconomic analysis and policymaking.

BSA analysis based on the new datasets can enhance surveillance activities by tracking the evolution of balance sheet vulnerabilities on a regular and timely basis. This provides a more comprehensive, up-to date diagnosis of balance sheet vulnerabilities - perhaps even as they develop - at a detailed level if needed. Earlier detection of balance sheet vulnerabilities can expand the range of policy options to address emerging vulnerabilities. The results can also be used as a basis for assessing risks in sectoral balance sheets using the contingent claims approach. 


\section{Appendix I Definitions of sectors}

Central banks: In most countries, separately identifiable institutions that, across countries, are subject to varying degrees of government control, engage in differing sets of activities, and are designated by various names (eg, central bank, reserve bank, national bank, or state bank).

General government: Institutional units that, in addition to fulfilling their political responsibilities and their role of economic regulation, produce principally non-market services (possibly goods) for individual or collective consumption and redistribute income and wealth.

Other depository corporations: All resident financial corporations (except the central bank) and quasi-corporations that are mainly engaged in financial intermediation and that issue liabilities included in the national definition of broad money (eg, commercial banks, merchant banks, savings banks, savings and loan associations, building societies and mortgage banks, credit unions and credit cooperatives, rural and agricultural banks, and travelers' check companies that mainly engage in financial corporation activities).

Other financial corporations: The remaining financial corporations, consisting of resident corporations or quasi-corporations, including those non-profit institutions that are (1) mainly engaged in the production of financial services (such as insurance), or (2) financed by subscriptions from financial enterprises and have the objective of promoting or otherwise serving the interest of those enterprises.

Non-financial corporations: Institutional units that are principally engaged in the production of market goods and non-financial services. ${ }^{23}$

Other resident sector: Households (all physical persons in the economy) that have as their principal functions the supply of labor, final consumption and, as entrepreneurs, the production of market goods and non-financial (possibly financial) services. This sector also includes non-profit institutions that are legal entities principally engaged in the production of non-market services for households and whose main resources are voluntary contributions by households.

Non-residents: Consists of all institutional units outside the country that enter into transactions with resident units, or have other economic links with resident units.

23 An institutional unit, according to the 1993 SNA is "an economic entity that is capable, in its own right, of owning assets, incurring liabilities and engaging in economic activities and in transactions with other entities ... [which] is able to take economic decisions and engage in economic activities for which it is itself held to be directly responsible and accountable at law," including entering into contracts. [(IMF, 1993aSNA, paragraph 4.2]). Finally, an institutional unit must be a resident unit in the domestic economy and be either (1) a household or (2) a legal or social entity whose existence is recognized by law or society independently of the persons or other entities that may own or control it (ie, government units, corporations, and non-profit institutions) [SNA 4.5]. (IMF, 1993a, paragraph 4.5). 


\section{Appendix II Definitions of financial instruments}

Financial assets are commonly defined as a subset of economic assets - entities over which ownership rights are enforced, individually or collectively, by institutional units and from which economic benefits can be derived by holding or using the assets over a period of time. $^{24}$

Financial assets are usually classified according to two criteria; the liquidity of the asset and the legal characteristics that describe the form of the underlying creditor/debtor relationship. For vulnerability purposes, financial instruments can be categorized using the terms described below

Currency consists of notes and coins that are of fixed nominal values and are issued by central banks or governments. Monetary gold (if under the effective control of the central bank) and SDRs can also be considered part of currency. Deposits include all claims on the central bank, other depository corporations, government units, or other institutional units that are represented by evidence of deposit.

Transferable deposits comprise all deposits that are exchangeable on demand at par and without penalty or restriction and directly usable for making payments by check, draft, giro order, direct debit/credit, or other direct payment facility.

Other deposits comprise all claims, other than transferable deposits, that are represented by evidence of deposit (eg, savings and fixed-term deposits, foreign currency nontransferable deposits).

Debt securities are negotiable instruments serving as evidence that units have obligations to settle by means of providing cash, a financial instrument, or some other item of economic value (eg, treasury bills, government bonds, corporate bonds and debentures).

Loans are financial assets that are created when a creditor lends funds directly to a debtor, and are evidenced by non-negotiable documents (including leases).

Shares and other equity comprise all instruments and records acknowledging, after the claims of all creditors have been met, claims on the residual value of a corporation.

Insurance technical reserves consist of net equity of households in life insurance reserves and pension funds and prepayments of premiums.

A financial derivatives contract is a financial instrument that is linked to a specific financial instrument, indicator, or commodity, and through which specific financial risks (such as interest rate risk, currency, equity and commodity price risk, and credit risk) can be traded in their own right in financial markets.

Other accounts receivable/payable include trade credit and advances and other such accounts.

Trade credit and advances comprise trade credit extended directly to corporations, government, non-profit institutions, households, and the rest of the world, as well as advances for work that is in progress (or is to be undertaken) and prepayment for goods and services.

24 For a detailed discussion of the definition of financial instruments, see the Monetary and Financial Statistics Manual (IMF, 2000, Section IV) and External Debt Statistics: Guide for Compilers and Users External Debt Guide (IMF, 2003, paragraphsparas. 3.13 to -3.38). 


\section{References}

Allen, M, C Rosenberg, C Keller, B Setser and N Roubini (2002): "A Balance Sheet Approach to Financial Crisis," IMF Working Paper 02/210 (Washington: International Monetary Fund).

Billmeier, A and J Mathisen (2006): "Balance Sheet Risks in a Dollarized Economy - The Case of Georgia," IMF Working Paper 06/173(Washington: International Monetary Fund).

Bussière, M and C Mulder (1999): "External Vulnerability in Emerging Market Economies: How High Liquidity Can Offset Weak Fundamentals and the Effects of Contagion," IMF Working Paper 99/88 (Washington: International Monetary Fund).

Calvo, G and C M Reinhart (2002): "Fear of Floating," Quarterly Journal of Economics, Vol. 117, No. 2 (May), pp. 379-408.

Gapen, M, D Gray, C-H Lim and Y Xiao (2004): "A Contingent Claims Approach to Corporate Vulnerability Analysis: Estimating Default Risk and Economy Wide Risk Transfer," IMF Working Paper 04/155 (Washington: International Monetary Fund).

Goldstein, M and P Turner (2004): Controlling Currency Mismatches in Emerging Markets (Washington: Institute for International Economics).

Gulde, A-M, D Hoelscher, A Ize, A Leone and D Marston (2003): "Dealing with Banking Crises in Dollarized Economies", in Charles Collyns and Russell Kincaid, eds., Managing Financial Crises: Recent Experience and Lessons from Latin America, IMF Occasional Paper No. 217 (Washington: International Monetary Fund).

International Monetary Fund (IMF), 1993a, System of National Accounts 1993 (Washington: International Monetary Fund).

(1993b): Fifth Edition of the Balance of Payments Manual (Washington: International Monetary Fund).

- (2000): Monetary and Financial Statistics Manual (Washington: International Monetary Fund).

(2001a): International Financial Statistics (Washington: International Monetary Fund).

(2001b): Government Finance Statistics Manual (Washington: International Monetary Fund). Available via the Internet: http://www.imf.org/external/pubs/ft/gfs/manual/index.htm.

(2002): International Investment Position: A Guide to Data Sources (Washington: International Monetary Fund Statistics Department).

(2003): External Debt Statistics: Guide for Compilers and Users (Washington: International Monetary Fund). Available via the Internet: http://www.imf.org/external/pubs/ft/eds/Eng/Guide/index.htm.

(2004a): Biennial Review of the Implementation of the Fund's Surveillance and of the 1977 Surveillance Decision - Overview, Modalities of Surveillance, Content of Surveillance, and Public Information Notice on the Executive Board Discussion (August 24). Available via the Internet: www.imf.org/external/np/pdr/surv/2004/082404.htm. Fund).

(2004b): "Liquidity Management" (unpublished; Washington: International Monetary

(2004c): Compilation Guide on Financial Soundness Indicators (Washington: International Monetary Fund). Available via the Internet: https://www.imf.org/external/np/sta/fsi/eng/2004/guide/index.htm.

- (2005): Global Financial Stability Report, April 2005 (Washington: International Monetary Fund). 
Johnston, R B, J Chai and L Schumacher (2000): "Assessing Financial System Vulnerabilities," IMF Working Paper 00/76 (Washington: International Monetary Fund).

Lima, J M, E Montes, C Varela and J Wiegand (2006): "Sectoral Balance Sheet Mismatches and Macroeconomic Vulnerabilities in Colombia, 1996-2003," IMF Working Paper 06/5 (Washington: International Monetary Fund).

Mathisen, J and M Torres (2005): "Balance Sheet Currency Mismatch and Liquidity Analysis," Belize - Selected Issues, IMF Country Report 05/353 (Washington: International Monetary Fund), pp. 16-26.

Reinhart, C M, K S Rogoff and M A Savastano (2003a): "Debt Intolerance," in William Brainard and George Perry, eds., Brookings Papers on Economic Activity, No. 1, pp. 1-74.

- (2003b),"Addicted to Dollars," NBER Working Paper No. 10015 (Cambridge, Massachusetts: National Bureau of Economic Research).

Roubini, N and B Setser (2004): Bailouts and bail-ins? Responding to Financial Crisis in Emerging Economies (Washington: Institute for International Economics).

Rosenberg, C, I Halikas, B House, C Keller, J Nystedt, A Pitt and B Setser (2005): DebtRelated Vulnerabilities and Financial Crises: An Application of the Balance Sheet Approach to Emerging Market Countries, IMF Occasional Paper No. 240 (Washington: International Monetary Fund). 